\title{
ACE VS. CBIT: WHICH IS BETTER FOR INVESTMENT AND WELFARE?
}

\author{
DOINA MARIA RADULESCU \\ MICHAEL STIMMELMAYR
}

\section{CESIFO WORKING PAPER NO. 1850 \\ CATEGORY 1: PUBLIC FINANCE \\ NOVEMBER 2006}

Presented At CESifo Venice Summer Institute, WORKSHOP ON

“The Future of CAPITAL InCOME TAXATION”, JUly 2006

An electronic version of the paper may be downloaded

- from the SSRN website:

- from the RePEc website:

www.SSRN.com

- from the CESifo website:

www.RePEc.org

www.CESifo-group.de 


\title{
ACE VS. CBIT: WHICH IS BETTER FOR INVESTMENT AND WELFARE?
}

\begin{abstract}
This paper analyses the switch to an ACE or to a CBIT type of tax system starting from the present German tax system. We show that in case an ACE type of reform is financed by an increase in the VAT and not in the profit tax, it might be preferred to a CBIT even in the context of an open economy. Moreover, the required exogenous increase in the profit tax rate cannot ensure revenue neutrality on its own due to the negative general equilibrium effects it triggers on the whole economy. For a CBIT, the exogenous reduction in the tax rates on corporate and non-corporate profits leads to better results than when we allow for an endogenous change in the VAT. The best results arise when the CBIT is accompanied by a provision for immediate write-off and a lower profit tax or when the ACE with no additional capital gains taxation on the household side is financed by an increase in the VAT.
\end{abstract}

JEL Code: C68, D58, D92, E62, H25.

Keywords: capital income taxation, computable general equilibrium modeling, welfare analysis.

\author{
Doina Maria Radulescu \\ Center for Economic Studies and CESifo \\ at the University of Munich \\ Schackstr. 4 \\ 80539 Munich \\ Germany \\ radulescu@ces.vwl.uni-muenchen.de
}

\author{
Michael Stimmelmayr \\ Center for Economic Studies and CESifo \\ at the University of Munich \\ Schackstr. 4 \\ 80539 Munich \\ Germany \\ Stimmelmayr@ces.vwl.uni-muenchen.de
}

September 2006

The authors are particularly grateful for the comments by Christian Keuschnigg and Peter Birch Sørensen, the helpful discussions by Marcel Gerard and Andreas Peichl as well as various participants at different conferences for their suggestions. 


\section{Introduction}

Since in most countries the tax law provides for a deduction of debt interest when computing the profit tax base, debt finance is at an advantage compared to financing an investment via retained earnings. In order to equalize the opportunity cost of debt and equity, tax professionals have designed two polar reform proposals, namely the Comprehensive Business Income Tax (CBIT) and the Allowance for Corporate Equity $(\mathrm{ACE})^{1}$ to counteract this problem. The CBIT was developed by the US Treasury Department at the beginning of the nineties whereas the ACE was elaborated by the IFS CAPITAL TAxes Group (1991) at the same time.

Under the former reform proposal neither the incurred interest on debt nor any imputed return on equity may be deducted against the profit tax base. As opposed to this, the second reform proposal, the ACE, provides in addition to the deduction of incurred interest on debt for the deduction of an imputed return on equity capital against the profit tax base of a firm (Bond, 2000; Cnossen, 2000; Devereux and Freeman, 1991). Accordingly, compared to the present tax systems enforced in all OECD countries, ${ }^{2}$ the user cost of capital for a debt financed investment would increase under the CBIT proposal, whereas the user cost of capital for an investment financed by internal equity could be reduced under the $\mathrm{ACE}$.

In this paper we develop a computable general equilibrium (CGE) model to analyze the implications of these two reform proposals with regard to the firms' investment behavior and households' welfare. To our knowledge, a comparative quantitative assessment of the efficiency and welfare aspects of these two reform proposals within the framework of a dynamic CGE model is lacking. Our paper tries to fill this gap by first comparing the neutrality properties and second by computing the efficiency and welfare effects arising from each of the two reform alternatives. ${ }^{3}$ The applied CGE model resembles a two

\footnotetext{
${ }^{1}$ For a detailed discussion on the ACE see BoAdway And Bruce (1984) and Devereux and FreeMAN (1991).

${ }^{2}$ In all OECD countries incurred interest on debt is deductible aginst taxable corporate profits, whereas the opportunity cost of equity capital does not face any favorable tax treatment in any OECD country. (OECD ,1991)

${ }^{3}$ There exists a study by FEHR AND WIEGARD (2003) which assesses the impact of introducing an
} 
country model where the home country consists of a two sector economy and an infinitively lived agent on the household side. ${ }^{4}$ Moreover, given the present discussions in different countries which aim at reforming the tax system one way or the other, this topic seems to be an up-to-date issue. On the one hand, in Germany, the German Council of Economic Advisors (GCEA) (2005, 2006) suggested introducing a combination of a Dual Income Tax with an ACE and for Switzerland, Keuschnigg (2005) also designed a growth oriented Dual Income Tax which also features an ACE. On the other hand, the ruling coalition's most recent reform proposal (Bundesfinanzministerium 2006) advances the idea of a lower corporate tax of 30 per cent and the partial abolition of debt interest deductibility thus moving in the direction of a CBIT. In addition, a similar idea was also put forward in the US by the President's Advisory Panel on Tax Reform (2006) who proposed for the taxation of large businesses a profit tax of 30 per cent and the abolishment of debt interest deductibility. ${ }^{5}$

Based on the premise that each tax reform should be implemented on a revenue neutral basis, the introduction of the ACE requires either an increase in the corporate income tax rate, an increase in another tax such as the VAT or a reduction in government transfers since it envisages a narrower tax base compared to the currently existing tax systems.

As opposed to the introduction of an ACE, under the CBIT, the corporate tax rate can under certain circumstances even be reduced due to the broader tax base which this proposal brings about.

When performing the simulations, we also rely on an adjustment in the VAT rate instead, or in addition to, the change in the corporate tax rate - to assure revenue neutrality under each of the two reform proposals. According to the above predictions, the simulations results show, in case the $\mathrm{ACE} / \mathrm{ACNE}^{6}$ (Allowance for corporate and non-

ACE in Germany, however it just considers this reform alternative and not a CBIT as well. Moreover, the model applied by these authors is an OLG model and it does not distinguish between firms of different legal form and does not feature an endogeneous portfolio choice by households.

${ }^{4}$ Currently, the CGE model is calibrated to the German economy. A detailed model documentation can be received on request from the authors.

${ }^{5}$ The present US tax code allows for debt interest deductibility and there are 8 tax brackets the lowest of 15 per cent and the highest of 39 per cent which apply to large businesses (The President's Advisory Panel on Tax Reform 2005).

${ }^{6}$ Since IFOMod, the dynamic CGE model applied here features both corporate and non-corporate 
corporate equity) is financed by an exogenous increase in the tax rates on corporate and non-corporate profits, the additional tax revenue collected is not sufficient to finance the reform. Therefore, the reform proposal needs to be accompanied either by an additional reduction in transfers or increase in the VAT rate. This outcome occurs since within the framework of our dynamic general equilibrium model, the tremendous rise in the profit tax rate has considerable negative economy-wide repercussions leading to capital decumulation and a shrinking tax base for all other taxes as well. These kind of second order effects accompanying any tax reform can only be determined by dynamic CGE models and are increasingly important to ensure a tax reform is undertaken in a sustainable way.

The simulations of the CBIT show that the exogenous decline in the corporate tax rate which may accompany such a reform has significant positive effects and leads to better results in economic growth and welfare. Overall, the policy reforms which have the most significant positive effects on macroeconomic variables and welfare are first the CBIT combined with a provision for immediate write-off. Under this scenario, the capital stock and labour demand increase triggering an increase in long-run GDP by around 10 per cent. Second, the ACE/ACNE with no additional capital gains taxation on household level also produces positive welfare results. Here, the long run capital stock increases by 20.5 per cent leading to a significant upward swing in GDP by 9.1 per cent. To ensure a comparable treatment of different types of capital income on household level we also consider scenarios which apply a capital gains tax as well. These simulations however, as well as the CBIT with no special depreciation allowances do not perform well and even lead to welfare losses.

The remaining part of the paper is structured as follows: The next Section presents a thorough comparison of the two fundamental reform alternatives. Section three then develops the general equilibrium model with special focus on the investment and financial behavior of corporate and non-corporate firms under these two reform proposals. Section four presents the simulation results and detailed economic interpretations, in Section five we perform a sensitivity analysis with respect to the most important parameters and the firms, we extend the allowance for equity to non-corporate firms to ensure an equal treatment of equity across firms of different legal form. 
last Section concludes.

\section{ACE vs. CBIT}

The ACE was elaborated by the IFS CAPITAL TAxes Group in 1991, however, the idea of considering an imputed interest on equity was first advanced by BOADWAY AND BRUCE in 1984. The reformers introduced the idea of such a tax system since they considered several shortcomings of the British tax system of that time. First, omitting the cost of equity finance drives a wedge between the pre- and post-tax returns of an investment financed by equity. Therefore, investments that do not provide sufficient returns which cover both the tax bill and offer the investor at least the market rate of return, will not be taken into consideration (IFS Capital Taxes Group 1991). ${ }^{7}$ Moreover, by still providing for debt interest deductibility, there continues to exist a bias in favor of debt-financed investments (BOND, 2000).

This reform was even introduced in Croatia between 1994 and 2001 such that we can speak of not only a theoretical concept but of something that has been tried in practice as well ( KEEN AND KING 2002).

Thus, in a closed economy, by introducing an ACE, the cost of capital for an investment financed via retained earnings is reduced (BOND, 2000) and as long as the deducted costs of equity and debt finance are equal, there is no particular advantage for one of the two sources of finance. Under these circumstances the ACE is favoured relative to the CBIT since it reduces the overall cost of capital of the firm.

In addition, the ACE in its pure form would also require that interest income is tax exempt at the personal level, such that this kind of tax system is equivalent to a cash-flow income $\operatorname{tax}^{8}{ }^{9}$ (LAmMersen, 2002; WAgner, 1999; FeHr AND Wiegard

\footnotetext{
${ }^{7}$ Additionally, since at the beginning of the nineties, British companies still relied on the historical cost accounting method for reporting profits, the effect of inflation was to increase the tax base in nominal terms such that the burden of taxation increased (IFS Capital Taxes Group, 1991)

${ }^{8}$ Under the cash flow tax, investment expenditures can be immediately written off when they are undertaken (BOADWAY and BRUCE, 1984).

${ }^{9}$ For the simulation exercise we, however, disregard this issue and just consider the deduction of
} 
1999, Devereux and Freeman, 1991). In essence, a pure ACE will exempt the cost of raising finance at the company level from taxation and will just subject the profits exceeding a 'normal rate of return' to taxation (IFS Capital Taxes Group, 1991). The implementation of such a tax system, however, poses some difficulties since a large amount of information is required about which interest rate should be imputed (BOADWAY And Bruce 1984, Bond And Devereux 1999). ${ }^{10}$ Moreover, financial neutrality is only guaranteed under the ACE if the imputed rate of return on equity capital equals the interest rate paid on debt. In case the protective interest rate exceeds the interest rate paid on debt, non-profitable investment projects might even be subsidized under the ACE. Such an outcome would be similar to the effects resulting from accelerated depreciation. On a theoretical basis, if the imputed rate of return on equity capital is, however, chosen appropriately, intertemporal and investment neutrality is achieved since the post- and pre-tax rates of return are adjusted (IFS Capital Taxes Group, 1991). In this case the households' rate of time preference will equal the marginal product of capital. ${ }^{11}$

An additional question to be asked in this context regards the issue whether the ACE should be extended such as to apply to self-employed as well. In this constellation, some difficulties might arise since it is problematic to distinguish which assets belong to the company and which to the shareholder (ISAAC, 1997). Considering the definition of the equity to be deducted, this could be measured for instance as the book value of assets net of debt (Devereux and Freeman, 1991). Regarding the viability of such a tax system in a world of high capital mobility, e.g. for outward investments by German companies abroad, an ACE would just apply to remitted and distributed profits to Germany. In the case of inward investment, for countries which apply the exemption system for double tax relief, things would not change to a large extent while in countries which apply the tax credit system (like the US), the taxpayer would have to pay the difference to the higher

a protective interest rate on equity capital, since we are just interested in comparing the two reform proposals with respect to their investment incentives and revenue implications. To ensure interest income and earnings on firm shares are treated in a similar way at household level we perform different simulations which also allow for the taxation of capital gains on household level.

${ }^{10}$ The IFS Tax Group favors in this case a medium-term gilt (IFS Capital Taxes Group, 1991).

${ }^{11}$ In our simulations however, a tax on interest income still aplies such that only investment but not intertemporal neutrality will be guaranteed. 
tax bill. ${ }^{12}$ As also noted by the IFS Capital Taxes Group (1991), the ACE system would tend to favour domestic investment because of the neutrality of the domestic tax system versus the non-neutrality of other countries' systems.

A controversial aspect emerges if we consider the fact that the ACE basically just taxes economic rents. Therefore, firms which earn just or less than the minimum required return would pay little or even no tax, while the most profitable enterprises will face the highest tax bill since they earn the highest returns. Clearly, it is debatable whether such a situation is desirable, mostly if we consider multinational companies to be usually the most profitable ones (BOND, 2000). In this context, the question might arise, why one would not think of simply reducing the statutory tax rate, thus providing a clear and simple signal to international investors. However, just reducing the statutory tax rate would not really address the issue of achieving neutrality with regard to the source of finance since debt finance would continue to be at an advantage compared to equity finance.

The main critique raised with regard to the ACE addresses the fact that the narrowing of the tax base has to be accompanied by a higher tax rate to achieve a certain tax revenue (IsAAC, 1997). Such an outcome is less desirable in a world of high capital mobility where a higher statutory tax rate has a negative signalling effect for multinational firms. Nevertheless, because of the limitation of the imputation system under the IFS Capital Taxes Group (1991) proposal, additional revenue can be achieved from taxing distributed profits at the personal level. Under a full imputation system, the tax on all profits can be credited against the shareholder's personal income tax, while under the new proposal only the tax paid on the normal rate of return can be credited against the shareholder's personal tax bill. Using an average of real revenues over the period 19711990, Devereux And Freeman (1991) compute a revenue-neutral tax rate of 45 per cent, which is about ten percentage points higher compared to the prevailing tax rate in the UK at that time.

\footnotetext{
${ }^{12}$ See also ISAAC (1997) fot the discussion on the effect of the ACE on inward and outward investment in the case of the UK.
} 
Lastly, a further main advantage of such a tax system, is that any schedule of depreciation allowances, i.e. providing for an immediate write-off or allowing for geometric digressive depreciation over the life of an asset - does not change the present value of tax payments (Devereux and Freeman, 1991 and Bruchner, Gassner, RienerMiCHELER 2000). Allowing for accelerated depreciation for instance reduces on the one hand the tax base of the profit tax in the current period. On the other hand it also reduces the accounting stock of capital and thus the base which is multiplied with the protective interest to compute the ACE in the next period (KEEN AND KInG, 2002). Therefore, such a reform increases the efficiency of a tax system. In contrast, under a conventional corporate tax system, the tax depreciation promotes tax savings such that the shadow price of capital also depends on the depreciation system in place (FEHR AND WIEGARD, 2003).

Regarding the treatment of risk and risky projects, the deduction of the imputed return on equity capital under the ACE reduces the volatility of the expected return. This is true, since the reduced expected return of shareholders is exactly compensated by the reduced risk they bear. Accordingly, the government acts like a silent partner which shares both the return and some of the risk of a project (DEVEREUX AND FREEMAN 1991).

As opposed to the ACE proposal, the other reform alternative considered here, the CBIT, developed by the US Treasury Department (1992), raises the cost of capital for a debt financed investment since the incurred interest on debt is no longer deductible when computing the profit tax base.

Even though this reform induces a higher capital cost, it might be advisable for a government to adopt it if it can apply a lower profit tax rate due to the broader tax base (CNossen, 2000). This is especially the case for a small open economy characterized by high capital mobility. Nevertheless, this line of arguments only holds if we assume that in order to achieve a given amount of government revenue, just the profit tax rate can and thus has to be altered. However, under the assumption that such reforms can also be financed by a change in the VAT (so by an increase in case of an ACE), it is not clear-cut 
that the CBIT is to be preferred in case of a small open economy, if a country wants to attract investors both by offering low statutory tax rates and a narrow tax base for corporate profits.

\section{The Model}

The following section introduces a detailed description of the dynamic CGE model which is applied to assess the quantitative impact of introducing the ACE/ACNE or the CBIT reform proposal. ${ }^{13}$

\subsection{Production}

Optimal investment behavior of both corporate $(C)$ and non-corporate $(N)$ firms is derived from an intertemporal investment model with convex adjustment costs. Moreover, since we mainly focus on the effects of the tax reform on welfare, we model the household sector using the traditional Ramsey model of an infinitely lived agent. ${ }^{14}$ Beside the government, the Rest of the World (RoW) is the model's fourth building block which completes the general equilibrium framework.

We start with a basic neoclassical, linear homogenous production technology, $Y^{f}=$ $F\left(K^{f}, L^{f}\right)$, with capital, $K$ and labour, $L$, as input factors. ${ }^{15}$ The price of the output good, $Y^{f}$, is normalized to unity and additionally, each firm incurs adjustment costs of $J^{f}\left(I^{f}, K^{f}\right)$ representing declining marginal returns of capital formation. ${ }^{16}$

\footnotetext{
${ }^{13}$ The model does not yet incorporate multinational firms and cross country ownership of firm equity. Thus, the welfare effects under the present constellation assume that resident taxpayers are the owners of the firms and we thus also abstract from the tax competition issue at this stage. The theoretical arguments of the effects of an ACE in case of countries applying the crediting or the exemption method can be found in ISAAC (1997). ISAAC (1997) also gives a broad overview on how other countries might react if a country like the UK would decide to move to an ACE type of tax system.

Moreover, in case of multinational firms which can decide to locate their production elsewhere and export to the domestic markets, BOND (2000) shows that a tax on rents like the ACE, can be avoided. Therefore, even if such a tax does not affect the cost of capital since it only falls on economic rents, if it is too high, it will be avoided by multinational firms, thus deterring domestic investment (BOND, 2000)

${ }^{14}$ The complete model documentation can be received on request from the authors.

${ }^{15}$ The superscript $f \in\{C=$ corporate, $N C=$ non-corporate $\}$ denotes the type of a particular firm.

${ }^{16}$ The adjustment cost function is assumed to be linearly homogeneous in investments, $I$ and capital, $K$
} 
Both firm types hire labour and accumulate capital to maximize their value. Thereby, corporate profits are subject to double taxation, first, by the profit tax, $\tau^{P, C}$, which is levied on firm level and thereafter on personal level by the dividend tax, $\tau^{D}$, in case of distributed profits ${ }^{17}$ or by the capital gains tax, $\tau^{G, f}$, in case of profit retention. Profits of non-corporate firms are taxed only once, namely at the personal level at the income tax rate, $\tau^{P, N}$, of the firm owner.

Capital accumulates over time whenever gross investment, $I_{t}^{f}$, exceeds the depreciation of the existing capital stock, $\delta K_{t}^{f}:{ }^{18}$

$$
G K_{t+1}^{f}=I_{t}^{f}+(1-\delta) K_{t}^{f}
$$

Concerning debt policy, we assume that interest payments on debt include an additional premium $m\left(b^{f}\right)$, e.g. agency cost of debt, which is a function of the debt capital ratio, $b^{f}=B^{f} / K^{f}$, of the firm. These agency costs are increasing in $b^{f}$, reflecting the larger risk of bankruptcy prevailing, if the debt capital ratio of a firm rises and therewith the non-tax cost of default. ${ }^{19}$ Debt accumulates according to:

$$
G B_{t+1}^{f}=B N_{t}^{f}+B_{t}^{f}
$$

Thus, next period's stock of debt, $B_{t+1}^{f}$, is given by the existing stock of debt, $B_{t}^{f}$, and new debt, $B N_{t}^{f}$ incurred.

The next equation shows net of tax profits $\pi_{t}^{f}$ defined as output $Y_{t}^{f}$, less adjustment costs $J_{t}^{f}$, wage payments $w_{t} L_{t}^{f}$, depreciation $\delta K_{t}^{f}$, interest and agency cost on debt $\left(i_{t}^{B H}+\right.$ and convex in investment. In the steady state adjustment costs are zero such that they do not influence the steady state solution.

${ }^{17}$ According to the German "Halbeinkünfteverfahren", dividends, $D$, are first taxed on the firm level and then half of distributed dividends are once again taxed on the personal level. To account for this imputation system, we take only half of the statutory tax rate applied to dividend income for the simulations. Moreover, effectively there is no capital gains tax in Germany but the variable, $t^{G, f}$, is carried along for reasons of completeness.

${ }^{18}$ The growth factor $G=(1+g)$, enters the model as we allow for an exogenous trend growth in labour productivity at rate $g$. Thus, in a balanced growth equilibrium the capital stock as well as all other variables grow at the rate $g$.

${ }^{19}$ The agency cost of debt, $m=m\left(b^{f}\right)$, are strictly concave implying that the first and second derivative, $m^{\prime}\left(b^{f}\right)>0$ and $m^{\prime \prime}\left(b^{f}\right)$, are positive. 
$\left.m^{f}\right) B_{t}^{f}$ and the tax liability of the firm $T_{t}^{P, f}$ :

$$
\begin{gathered}
\pi^{f}=Y^{f}-J^{f}-w^{f} L^{f}-\delta K^{f}-\left(i^{B H}+m^{f}\right) B^{f}-T^{P, f}, \\
\left.T^{P, f}=\begin{array}{cc}
\tau^{P, f} & {\left[Y^{f}-J^{f}-w^{f} L^{f}-\delta K^{f}-m^{f} B^{f}\right.} \\
&
\end{array} \quad-z_{1} i^{B H} B^{f}-z_{2} i^{E}\left(K^{f}-B^{f}\right)-z_{3} I N^{f}\right] .
\end{gathered}
$$

Hence, $\tau^{P, f}$ has to be interpreted as a source tax on corporate profits. The tax parameters $z_{1}$ and $z_{2}$ denote whether the incurred interest on debt and equity capital is tax deductible or not. In case both parameters are set to zero, $z_{1}=z_{2}=0$, neither the interest on debt nor the imputed return on equity, denoted by $i^{E}$ are tax deductible, as proposed under the CBIT. As opposed to that, if we set $z_{1}=z_{2}=1$, we model an ACE/ACNE since both the interest on debt and the imputed return on equity are tax deductible. The imputed return is multiplied with the value of the firm's equity, namely $K^{f}-B^{f}$. Under the present German tax rules $z_{1}=1$ and $z_{2}=0$ holds, implying that only interest payments on debt are tax deductible. The other tax parameter $z_{3}$ represents the tax allowances for net investments $I N^{f 20}$.

Furthermore, regarding net investments of a firm, ${ }^{21} I N_{t}^{f}=I_{t}^{f}-\delta K_{t}^{f}$, can either be financed via a reduction in distributions/dividends and thus out of retained earnings $\left(\pi_{t}^{f}-D i v_{t}^{f}\right)$, via issuing new equity, $V N_{t}^{f}$, or externally via new debt, $B N_{t}^{f}$. Accordingly the cash flow identity states:

$$
I N_{t}^{f}=\left(\pi_{t}^{f}-D i v_{t}^{f}\right)+V N_{t}^{f}+B N_{t}^{f}
$$

A corporate firm can draw on all of the above mentioned three sources of finance. In case of a non-corporate firm however, all profits are distributed, $\pi_{t}^{N}=D i v_{t}^{N}$, such that the marginal investment needs to be financed either by new share issues or new debt.

Finally, the net of tax return on corporate and non-corporate equity is given by net

\footnotetext{
${ }^{20}$ If $z_{3}=0$ we have the case of economic depreciation. If $z_{3}=1$ we allow for a full immediate write-off and and $\tau^{P, f}$ can be interpreted as a cash-flow tax.

${ }^{21}$ We assume that replacement investments are always financed internally.
} 
of tax dividend payouts and net of tax capital gains:

$$
r_{t}^{V, f} V_{t}^{f}=\left(1-\tau^{D, f}\right) D i v_{t}^{f}+\left(1-\tau^{G, f}\right)\left[G V_{t+1}^{f}-V_{t}^{f}-V N_{t}^{f}\right]
$$

Of course, for non-corporate firms no dividend tax applies.

\subsection{Intertemporal Optimization}

The firms of each sector seek to maximize their value and therefore choose their intertemporal pattern of labor demand, investment and new debt optimally. Thereby, the firm value $V^{f}$ will increase with the size of the capital stock accumulated and fall with the level of debt inherited from the past. At the beginning of each planning period, $t$, the capital stock and level of debt are, however, exogenous, as they are historically predetermined from previous actions. The differential equation determining the end of period firm value is given by: ${ }^{22}$

$$
\begin{aligned}
V_{t}^{e, f} & =\chi_{t}^{f}+\frac{G V_{t+1}^{e, f}}{1+r e_{t+1}^{f}}, \\
\text { with } \chi_{t}^{f} & =\frac{\theta^{D, f}}{\theta^{G, f}} D i v_{t}^{f}-V N_{t}^{f} .
\end{aligned}
$$

The variable $\theta$ denotes a tax factor which is defined as 'one minus the respective tax rate'. Hence, the end of period market value of a firm is determined by the present value of all future net of tax dividend payments less new equity injections. The net dividend flow is discounted at the cost of equity, $r e^{f}=r^{V^{f}} /\left(1-\tau^{G, f}\right)$, which is the required gross return on firm level.

Using the value function, and assuming that investment is optimized from period $t+1$ onwards, resulting in the value function $V\left(K_{t+1}^{f}, B_{t+1}^{f}\right)$, we can find today's optimal labor demand, investment and financial behavior by maximizing the Bellman Equation of Dynamic Programming:

$$
\begin{aligned}
V^{e, f}\left(K_{t}^{f}, B_{t}^{f}\right)=\max _{L^{f}, I^{f}, B N^{f}} & {\left[\chi_{t}^{f}+\frac{G}{1+r e_{t+1}^{f}} V^{e, f}\left(K_{t+1}^{f}, B_{t+1}^{f}\right)\right], } \\
\text { s.t. } & (1) \text { and }(2) .
\end{aligned}
$$

\footnotetext{
${ }^{22}$ Caution, the variable $V_{t}^{f}$ denotes the beginning of period firm value, whereas the variable $V_{t}^{e, f} \equiv$ $\left(1+r e_{t}^{f}\right) V_{t}^{f}$ refers to the end of period firm value.
} 
Defining the shadow prices of capital $q_{t}^{e, f} \equiv d V_{t}^{e, f} / d K_{t}^{f}$ and debt $\lambda_{t}^{e, f} \equiv d V_{t}^{e, f} / d B_{t}^{f}$, respectively, ${ }^{23}$ as well as the following three tax parameters for corporate and non-corporate firms:

$$
\begin{array}{rl|l}
\text { (a) } \gamma^{D, C} & =\frac{\theta^{D, C} \theta^{P, C}}{\theta^{G, C}} & \gamma^{D, N}=\frac{\theta^{P, N}}{\theta^{G, N}} \\
\text { (b) } \gamma^{I, C} & =\left[\frac{\theta^{D, C}}{\theta^{G, C}}(1-\beta)+\beta\right]\left(1-z_{3} \tau^{P, C}\right) & \gamma^{I, N}=1-\frac{\tau^{P, N} z_{3}}{\theta^{G, N}} \\
\text { (c) } \Omega^{C}=\frac{\theta^{D, C}}{\theta^{G, C}} & \Omega^{N}=1
\end{array}
$$

the optimality conditions concerning the control variables labor, investment and new debt state:

$$
\begin{aligned}
& \text { (a) } L_{t}^{f}: w_{t}^{f}=F_{L, t}^{f}, \\
& \text { (b) } I_{t}^{f}: \frac{q_{t+1}^{e, f}}{\left(1+r e_{t+1}^{f}\right)}=\gamma^{D, f} J_{I}^{f}+\gamma^{I, f}, \\
& \text { (c) } B N_{t}^{f}: \frac{\lambda_{t+1}^{e, f}}{\left(1+r e_{t+1}^{f}\right)}=-\Omega^{f} .
\end{aligned}
$$

Optimal labor demand is determined by the equality between the marginal product of labor $F_{L, t}^{f}$ and the labor cost $w_{t}^{f}$. In equilibrium, the wage rate is determined endogenously such that it clears the labor market. Optimality condition (9b) delivers the condition which describes the firm's optimal investment policy: Optimal investment thus equates the present value of the marginal benefit arising from one additional unit of capital installed, namely $q_{t+1}^{f},{ }^{24}$ with the marginal cost incurred for carrying out this investment which is given by $\gamma^{D, f} J_{I}^{f}+\gamma^{I, f}$. Accordingly, the marginal cost of investing one unit of capital today is $\theta^{D, C} / \theta^{G, C}\left[\theta^{P, C} J_{I}^{C}+1\right]$ for a corporate firm and $\theta^{P, N} / \theta^{G, N} J_{I}^{N}+1$ for a non-corporate firm. ${ }^{25}$

\footnotetext{
${ }^{23}$ The shadow prices determine the increase in the value of the objective function resulting from a marginal increase in the stock variables capital or debt.

${ }^{24}$ The derived shadow prices for capital and debt are 'end of period shadow prices', since they resemble the derivative of the end of period firm values w.r.t. the stock variables capital and debt. These end of period shadow prices can easily be transformed into 'beginning of period' shadow price by applying the same procedure as for the firm value. Accordingly, the beginning of period shadow price for capital is given by: $q_{t+1}^{f}=q_{t+1}^{e, f} /\left(1+r e_{t+1}^{f}\right)$.

${ }^{25}$ Assuming there is no accelerated depreciation so $z_{3}=0$ and there are no new share issues available to finance marginal investments, so $\beta=0$.
} 
The envelope conditions concerning the stock variables capital and debt are:

$$
\begin{aligned}
\text { (a) } \quad K^{f}: \quad q_{t}^{e, f} & =\gamma^{D, f}\left[F_{K}^{f}-J_{K}^{f}+m_{f}^{\prime} b_{f}^{2}+\frac{z_{2} \tau^{P, f}}{\theta^{P, f}} i_{t}^{E}\right] \\
& -\left(\gamma^{D, f}-\gamma^{I, f}\right) \delta+\frac{q_{t+f}^{e, f}}{1+r e_{t+1}^{f}}(1-\delta) \\
\text { (b) } \quad B^{f}: \quad \lambda_{t}^{e, f} & =\gamma^{D, f}\left[-m_{f}-m_{f}^{\prime} b_{f}-\frac{1-z_{1} \tau^{P, f}}{\theta^{P, f}} i^{B H}-\frac{z_{2} \tau^{P, f}}{\theta^{P, f}} i^{E}\right]+\frac{\lambda_{t+1}^{e, f}}{1+r e_{t+1}^{f}}
\end{aligned}
$$

These equations enable us to determine the cost of capital which influences the investment decision of the firm as well as the cost of equity and debt finance which determine a firm's financing behavior. These behavioral margins are discussed in detail in the following sections.

\subsection{Financial Behavior}

Performing a comparative static analysis allows us to derive basic insights about the economic effects arising from the two proposed tax reform scenarios. In the following, we compute the effect of a marginal change in one tax rate on the marginal product of capital and the cost of equity, respectively, to examine how these changes in the tax rates affect the investment and financial behavior of firms. To start with, the financial behavior of firms is considered.

According to the Modigliani Miller Theorem (1958), the market value of a firm is independent of its capital structure in the absence of taxation. ${ }^{26}$ In the presence of taxes and agency costs, however, the different tax constellations create a preference for a specific source of finance.

The optimal level of a firm's indebtedness is achieved if the cost of equity finance equals the cost of debt finance. Substituting eq.(9c) into the envelope condition for the co-state variable debt shown in eq.(10b) the expression determining the optimal debt asset ratio is derived:

$$
r e^{f}-\frac{\gamma^{D, f}}{\Omega^{f}} \frac{z_{2} \tau^{P, f}}{\theta^{P, f}} i^{E}=\frac{\gamma^{D, f}}{\Omega^{f}}\left[m_{f}+m_{f}^{\prime} b_{f}+\frac{1-z_{1} \tau^{P, f}}{\theta^{P, f}} i^{B H}\right] .
$$

\footnotetext{
${ }^{26}$ In addition, the following three conditions have to be fulfilled such that the ModiGLiANi MiLlER Theorem holds: (1) perfect markets (i.e. no taxes or transaction costs), (2) cash flows that are independent of financial structure and (3) risk less debt such that firms and individuals can borrow and lend at a risk free interest rate.
} 


$$
\begin{array}{ll}
\text { C-Firm: } & \frac{{ }^{V} V^{C}}{\theta^{G, C}}-z_{2} \tau^{P, C} i^{E}=\theta^{P, C}\left[m_{C}+m_{C}^{\prime} b_{C}+\frac{1-z_{1} \tau^{P, C}}{\theta^{P, C}} i^{B H}\right] \\
N \text {-Firm: } & r^{V^{N}}-z_{2} \tau^{P, N} i^{E}=\theta^{P, N}\left[m_{N}+m_{N}^{\prime} b_{N}+\frac{1-z_{1} \tau^{P, N}}{\theta^{P, N}} i^{B H}\right] .
\end{array}
$$

The striking difference between the two cost of equity formulae for the two firm types is that the capital gains tax rate does not affect the cost of equity of non-corporate firms. This is so because non-corporate firms can not draw on retained earnings as a marginal source of finance, and accordingly the capital gains tax rate does not influence the financial decision.

If debt and equity are treated equally on the personal level, then both have to yield the same pretax return, namely $r e^{f}=i^{B H}$.

However, if a profit tax applies, debt financing incorporates the advantage of interest deductibility on corporate level, in case $z_{1}=1$, inducing a preference for debt finance in the size of $\tau^{P, f} i^{B H}$. Since the larger indebtedness increases the debt asset ratio, $b^{f}$, additional agency cost of $m_{f}^{\prime} b_{f}+m_{f}$ arise, reducing the advantage of debt finance.

The left hand side of the above equation is the effective cost of equity which is lower if we introduce an ACE/ACNE, implying $z_{2}=1$. Therefore, both the cost of equity and the cost of debt depend on whether debt interest and/or an imputed return on equity are tax deductible from the profit tax or not.

In case a CBIT is implemented, then both $z_{1}$ and $z_{2}$ equal zero and neither the cost of debt finance nor the cost of equity finance are tax deductible. Under that constellation there will be no particular preference for any of the two sources of finance:

$$
\begin{aligned}
\text { CBIT: } \quad r e^{f} & =\frac{\gamma^{D, f}}{\Omega^{f}}\left[m_{f}+m_{f}^{\prime} b_{f}+\frac{1}{\theta^{P, f}} i^{B H}\right] . \\
\text { C-Firm: } & \frac{r^{V^{C}}}{\theta^{G, C}}=\theta^{P, C}\left[m_{C}+m_{C}^{\prime} b_{C}+\frac{1}{\theta^{P, C}} i^{B H}\right], \\
\text { N-Firm: } & r^{V^{N}}=\theta^{P, N}\left[m_{N}+m_{N}^{\prime} b_{N}+\frac{1}{\theta^{P, N}} i^{B H}\right] .
\end{aligned}
$$

From Figure 1 we can see that abolishing the possibility to deduct debt interest from the profit tax base increases the cost of debt finance, while the cost of equity remains unchanged. If a preference of debt finance prevailed, this is now reduced. Accordingly, 
less debt will be incurred resulting in a lower debt asset ratio. The optimal debt asset ratio moves to the left, to $b^{\prime}$.

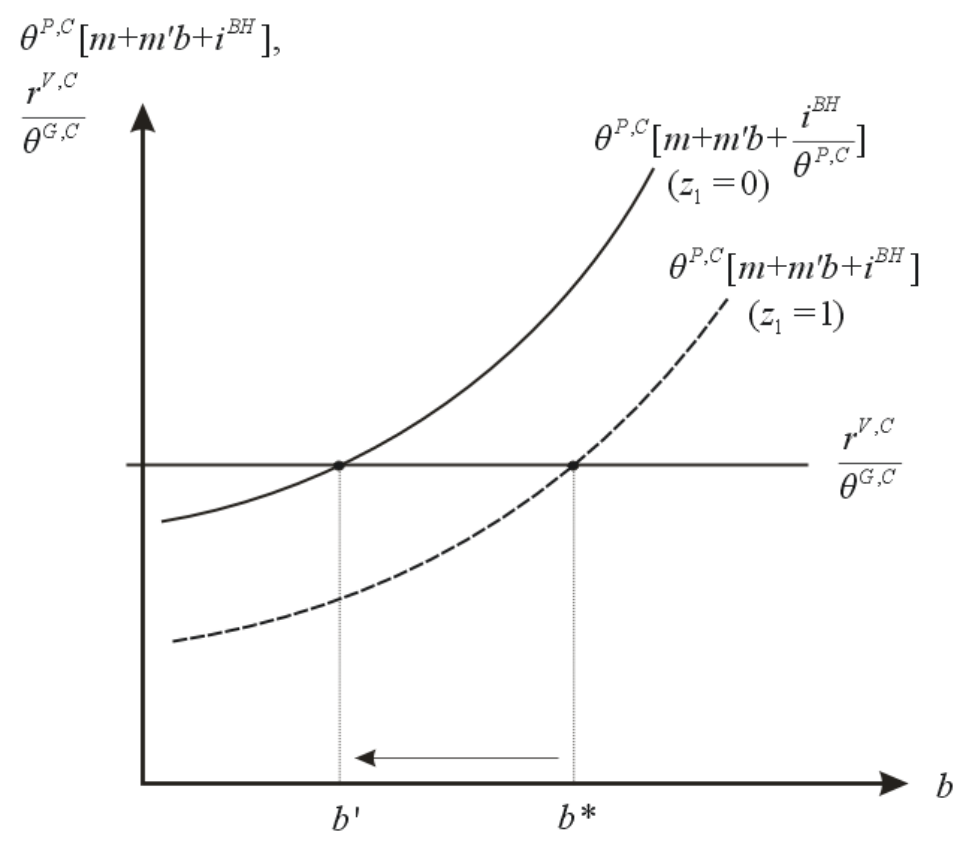

Figure 1: Change of the Optimal Debt Asset Ratio under CBIT

A similar neutrality property with respect to the source of finance is also achieved in case the policy reform follows an ACE/ACNE. Under this scenario both $z_{1}$ and $z_{2}$ equal one implying that both the imputed rate of return and debt interest are tax deductible:

$$
\begin{gathered}
\text { ACE/ACNE: } \quad r e^{f}-\frac{\gamma^{D, f}}{\Omega^{f}} \frac{\tau^{P, f}}{\theta^{P, f}} i^{E}=\frac{\gamma^{D, f}}{\Omega^{f}}\left[m_{f}+m_{f}^{\prime} b_{f}+i^{B H}\right] . \\
\text { C-Firm: } \quad \frac{r^{V^{C}}}{\theta^{G, C}}-\tau^{P, C} i^{E}=\theta^{P, C}\left[m_{C}+m_{C}^{\prime} b_{C}+i^{B H}\right], \\
\text { N-Firm: } \quad r^{V^{N}}-\tau^{P, N} i^{E}=\theta^{P, N}\left[m_{N}+m_{N}^{\prime} b_{N}+i^{B H}\right] .
\end{gathered}
$$

As we can see from eq. (13) introducing the possibility to deduct an imputed return from the tax base lowers the cost of equity. Accordingly, in Figure 2 the horizontal line depicting the cost of equity shifts downwards whereas the upward sloping cost of debt remains unchanged. Thus, if an ACE/ACNE is introduced the optimal debt asset ratio declines from initially $b^{*}$ to $b^{\prime}$. 


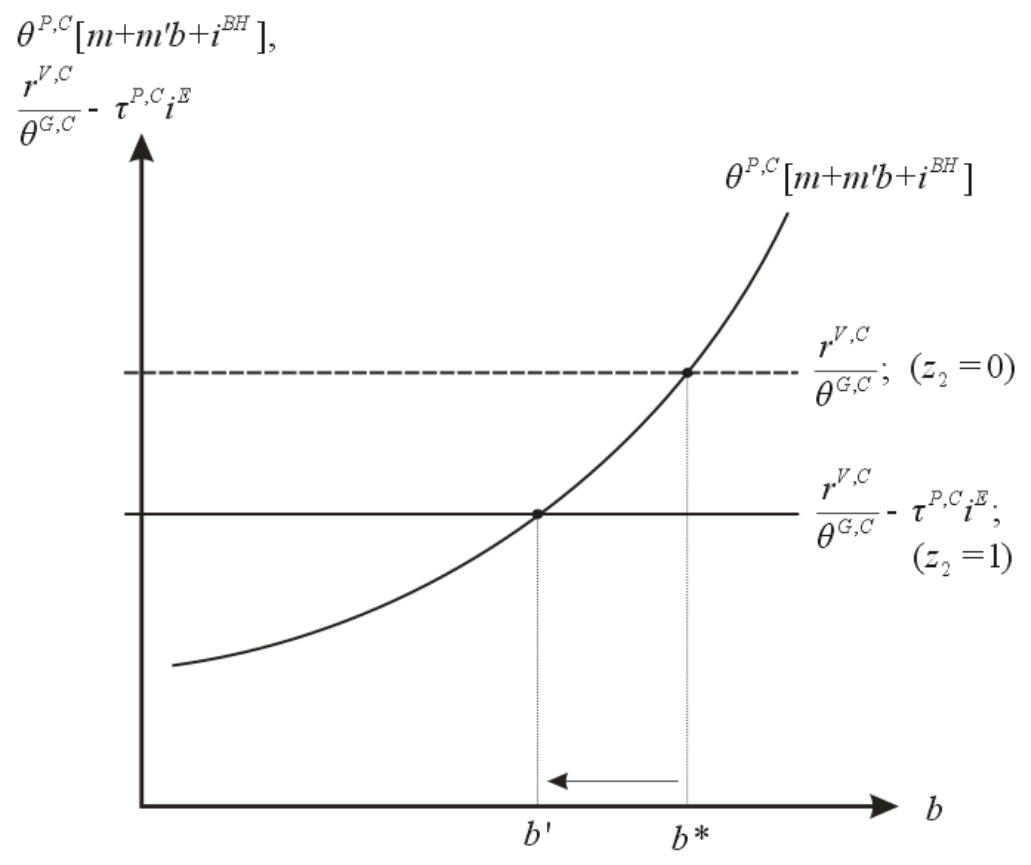

Figure 2: Change of the Optimal Debt Asset Ratio under ACE/ACNE

Moreover, in the case of an ACE/ACNE, the preference for a particular source of finance also depends on the magnitude of the imputed rate of return, $i^{E}$. Neutrality is achieved only insofar as $i^{E}=i^{B H}$ so when the imputed return equals the interest rate paid on debt (see eq. (13). The higher $i^{E}$ will be, the lower the cost of equity and the higher will then the incentive be to draw on retentions to finance investments vis-a-vis new debt.

In Figure 3, the initial debt asset ratio is denoted by $b^{*}$. If we allow for an increase in the imputed return which can be deducted from the tax base, $i^{E^{\prime}}>i^{E}$, the cost of equity will decline further implying a downward shift of the horizontal cost of equity line. Consequently, the optimal debt asset ratio shrinks to $b^{\prime}$.

To evaluate the effects of a marginal change in the tax rates on the financial decision of a firm, we analyze the change in the cost of equity stemming from a marginal change in the tax rate under consideration. Similar to Keuschnigg And Dietz (2004) or KeuschnigG (1991), we compute the percentage change in the cost of equity analogous to: $\widehat{r e^{f}} \equiv$ $d r e^{f} / r e^{f}$, where $d r e^{f}$ denotes the deviation from the initial value of $r e^{f}$. The relative 


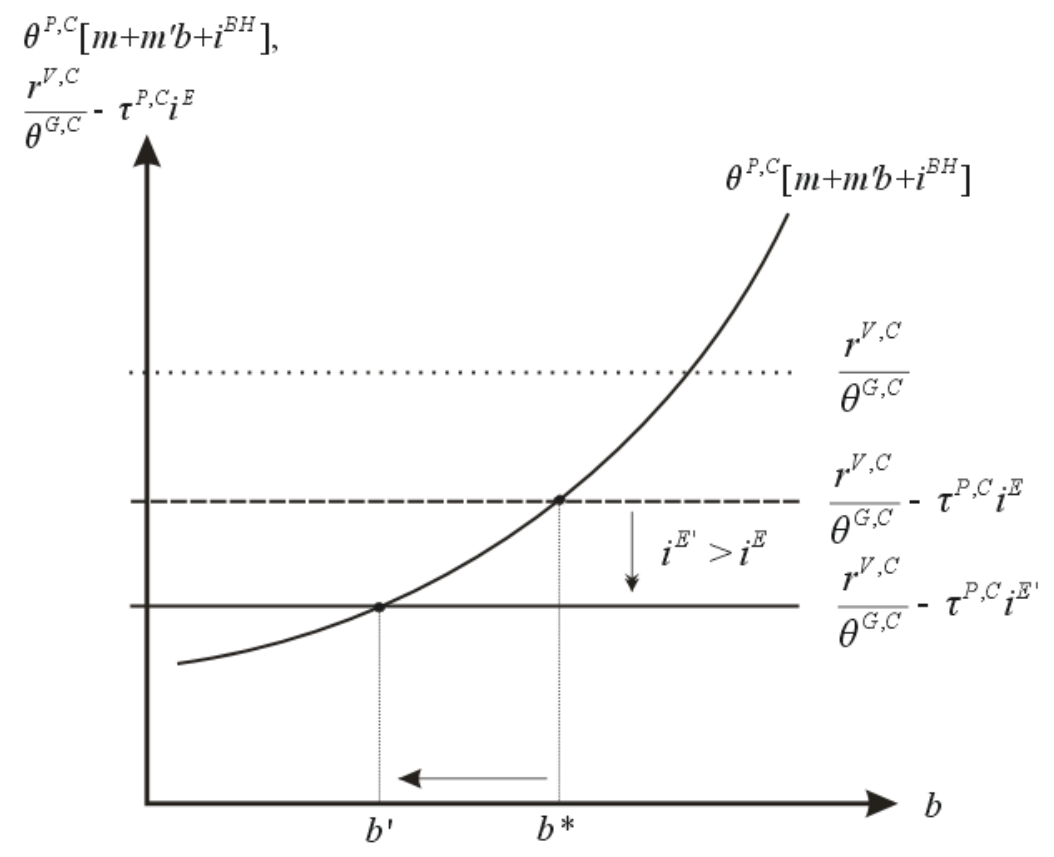

Figure 3: Increase in the Imputed Return under ACE/ACNE

change in the particular tax rate is then defined as $\hat{\tau} \equiv d \tau /(1-\tau)$ to avoid division by zero. Therefore, taking $r^{V^{f}}$ as given, we obtain in case a CBIT is applied:

$$
r e^{f}=\frac{r^{V^{f}}}{1-\tau^{G, f}} \quad \Rightarrow \quad \widehat{r e^{f}}=\widehat{\tau^{G, f}}
$$

According to eq. (14), under the CBIT the cost of equity is only affected by the capital gains tax, such that a one-percentage point increase in the capital gains tax rate also leads to a one-percentage point increase in the cost of equity capital.

Under the ACE/ACNE, besides the capital gains tax, the profit tax and the level of the imputed return can also induce a preference for either debt or equity finance. While a higher capital gains tax increases the cost of equity capital and thus induces a preference for debt finance (as a result the debt asset ratio $b$ increases), an increase in the profit tax will reduce the cost of equity capital. Accordingly, a larger profit tax rate will stimulate 
a preference for equity finance, implying a reduction in the debt asset ratio:

$$
\begin{aligned}
& \frac{d\left(r e^{f}-\tau^{P, f} i^{E}\right)}{d \tau^{G, f}}>0, \\
& \frac{d\left(r e^{f}-\tau^{P, f} i^{E}\right)}{d \tau^{P, f}}<0 .
\end{aligned}
$$

Under the ACE/ACNE, the overall effect on the financial behavior resulting from an increase in the profit tax rate is, however, less clear cut. On the one hand, the increase in the profit tax rate reduces the cost of equity as already discussed, on the other hand, it also reduces the cost of debt since debt interest is also tax deductible. Therefore, the dominating effect will depend on the relative difference between the imputed return and the interest rate on firm debt. If both are equal, both sources of finance are affected in an identical way. However, if the imputed return is higher (lower) than the return on debt, there will be a preference for equity (debt) finance.

Similar to an increase in the profit tax rate, a larger imputed return on equity capital ensures a reduction in the cost of equity capital, too:

$$
\frac{d\left(r e^{f}-\tau^{P, f} i^{E}\right)}{d i^{E}}<0
$$

Therefore, the higher the imputed return which can be deducted from the tax base, the lower the cost of equity and thus the higher the preference for equity finance will be. ${ }^{27}$ The debt asset ratio, $b$, accordingly declines (see also Figure 3).

\subsection{Investment Behavior}

Combining the expression for the shadow price of capital (9b) with the envelope condition for the co-state variable capital (10a) and substituting in equation (11), which determines the optimal use of debt, the cost of capital can be expressed as the weighted sum of the cost of equity capital and external capital, where the debt asset ratio, $b_{f}$, serves as a

\footnotetext{
${ }^{27} \mathrm{~A}$ detailed discussion on the magnitude of the imputed return in practice can be found in KEEN AND KING (2001) where the authors explain how the protective interest was set in the Croatian experiment.
} 
weighting factor:

$$
\begin{aligned}
& F_{K}^{f}-\delta=\underbrace{\frac{r e^{f}}{\gamma^{D, f}}\left(\gamma^{I, f}-\Omega^{f} b^{f}\right)-\underbrace{z_{2} \frac{\tau^{P, f}}{\theta^{P, f}}\left(1-b^{f}\right) i^{E}}_{\text {Advantage of ACE }}}_{\text {Cost of Equity }}+\underbrace{\left[\frac{1-z_{1} \tau^{i P, f}}{\theta^{P, f}} i^{B H}+m^{f}\right] b^{f}}_{\text {Cost of Debt }} \\
& \text { C-Firm: } \quad F_{K}^{C}-\delta=\left[\frac{{ }^{V^{C}}}{\theta^{P, C} \theta^{G, C}}-z_{2} i^{E} \frac{\tau^{P, C}}{\theta^{P, C}}\right]\left(1-b_{C}\right)+\beta \frac{{ }^{V^{C}}}{\theta^{P, C} \theta^{G, C}}\left[\frac{\theta^{G, C}}{\theta^{D, C}}-1\right], \\
& +\left[\frac{1-z_{1} \tau^{i P, C}}{\theta^{P, C}} i^{B H}+m_{C}\right] b_{C}-z_{3} \tau^{P, C} \frac{r^{V^{C}}}{\theta^{P, C} \theta^{G, C}}\left[1+\beta\left(\frac{\theta^{G, C}}{\theta^{D, C}}-1\right)\right] \\
& N \text {-Firm: } \quad F_{K}^{N}-\delta=\left[\frac{r^{V^{N}}}{\theta^{P, N}}-z_{2} i^{E} \frac{\tau^{P, f}}{\theta^{P, f}}\right]\left(1-b^{N}\right)+\left[\frac{1-z_{1} \tau^{i P, f}}{\theta^{P, f}} i^{B H}+m^{N}\right] b^{N} \\
& -z_{3} \tau^{P, N} \frac{r^{V^{N}}}{\theta^{P, N} \theta^{G, N}}
\end{aligned}
$$

Without taxes, the marginal investment must offer a rate of return at least equal to the interest rate, $F_{K}^{f}-\delta=i^{B H}$. With taxation, the cost of capital changes as shown in the above equation. The first term on the right hand side indicates the cost of equity finance. In case an $\mathrm{ACE} / \mathrm{ACNE}$ prevails, namely if $z_{2}=1$, the cost of equity is reduced by the amount of the tax advantage of the ACE/ACNE. The second term, the cost of debt finance consists of interest payments plus the agency cost. ${ }^{28}$

Inserting the relevant parameters for corporate firms into eq. (18) we can derive the following cost of capital formula for firms belonging to the corporate sector under the present tax schedule prevailing in Germany ${ }^{29}$ :

$$
F_{K}^{C}-\delta=\frac{r^{V}}{\theta^{G, C} \theta^{P, C}}\left(1-b_{C}\right)+\left(i^{B H}+m_{C}\right) b_{C}
$$

It is straightforward since we assumed the 'New View' of dividend taxation to apply, that only the capital gains and the profit tax rate affect the cost of capital.

\footnotetext{
${ }^{28}$ The propensity to invest also depends on the tax allowance for investments, $z_{3}$, which is included in $\gamma^{I, f}$ and reduces the actual tax burden if $z_{3}>0$.

${ }^{29}$ Remember that $\gamma^{D, C}=\frac{\theta^{D, C} \theta^{P, C}}{\theta^{G, C}}$ and $\gamma^{I, C}=\frac{\theta^{D, C}}{\theta^{G, C}}$ as well as $\Omega^{C}=\frac{\theta^{D, C}}{\theta^{G, C}}$. Moreover we assume $\beta=0$ indicating that there are no new share issues and that depreciation follows economic depreciation, $z_{3}=0$. Furthermore, we allow for the debt interest deductibility so $z_{1}=1$ and we disregard any allowance for corporate equity so $z_{2}=0$ :
} 


\section{CBIT}

If we analyze the effect of the CBIT on the cost of capital of either sector firm, both $z_{1}$ and $z_{2}$ have to be set equal to zero. Under this constellation of parameters the above cost of capital formula changes to:

$$
\begin{aligned}
F_{K}^{f}-\delta & =\left\{\frac{r e_{t}^{f}}{\gamma^{D, f}}\right\}\left(\gamma^{I, f}-\Omega^{f} b_{f}\right)+\left\{\frac{i^{B H}}{\theta^{P, f}}+m_{f}\right\} b_{f} . \\
\text { C-Firm: } \quad F_{K}^{C}-\delta & =\frac{{ }^{V^{C}}}{\theta^{P, C} \theta^{G, C}}\left(1-b_{C}\right)+\beta \frac{r^{V^{C}}}{\theta^{P, C} \theta^{G, C}}\left[\frac{\theta^{G, C}}{\theta^{D, C}}-1\right], \\
& +\left(\frac{i^{B H}}{\theta^{P, C}}+m_{C}\right) b_{C}-z_{3} \tau^{P, C} \frac{r^{V^{C}}}{\theta^{P, C} \theta^{G, C}}\left[1+\beta\left(\frac{\theta^{G, C}}{\theta^{D, C}}-1\right)\right] \\
\text { N-Firm: } \quad F_{K}^{N}-\delta & =\frac{r^{V^{N}}}{\theta^{P, N}}\left(1-b^{N}\right)+\left[\frac{i^{B H}}{\theta^{P, f}}+m^{N}\right] b^{N}-z_{3} \tau^{P, N} \frac{r^{V^{N}}}{\theta^{P, N} \theta^{G, N}}
\end{aligned}
$$

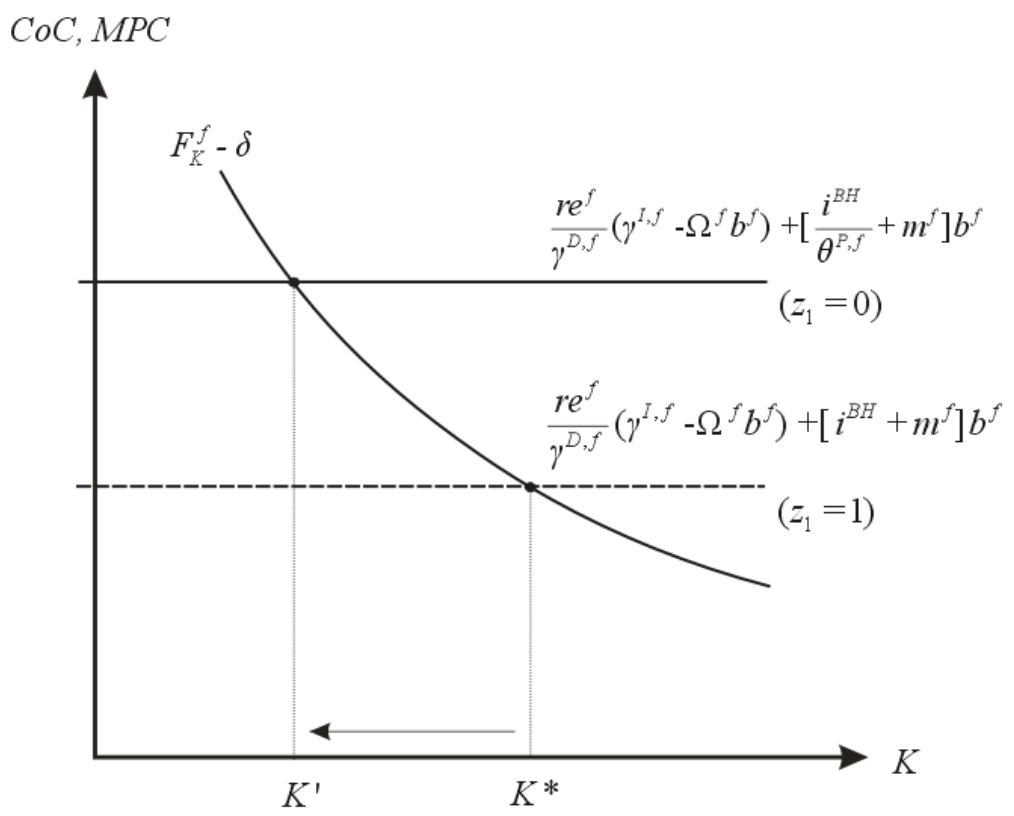

Capital Accumulation under the CBIT

As expected, the overall cost of capital increase under the CBIT, since incurred interest on debt is no longer tax deductible and hence the cost of debt finance is raised. Figure 4 illustrates the effect of introducing a CBIT on capital accumulation. The optimal capital stock is given by the intersection of the downward sloping marginal product curve with the cost of capital represented by the horizontal line. 
Introducing a CBIT, the horizontal cost of capital line shifts upwards. Due to the higher cost of capital a lower number of profitable investments which offer the minimum required rate of return are available. As a consequence, less investments will be carried out, implying that each firm operates at a lower capital intensity. Overall, a capital decumulation in the economy will occur. If we additionally allow for an immediate writeoff such that $z_{3}^{f}=1$ we see that such a provision leads to a decline in the cost of capital of both firm types and, assuming no agency cost of debt and equal rates of return across different asset types, such a scenario also leads to investment neutrality (see eq. (22)). It is in such a situation that the advantage of a CGE model become most clear. The simple comparative static does not show us which of the two opposite effects, the tax base broadening or the generous depreciation allowances will in the end prevail.

For the following comparative static analysis we ignore the possibility of external equity finance for corporate firms as well as the possibility of any immediate write off for both types of firms implying $\beta=0$ and $z_{3}^{f}=0$.

Differentiating the firm specific cost of capital formulae for corporate and non-corporate firms given in eq. (22) with respect to the tax rate under consideration:

$$
\begin{aligned}
& \text { C-Firm: } \quad \frac{d\left(F_{K}^{C}-\delta\right)}{d \tau^{P, C}}=\frac{r^{V}}{\left(1-\tau^{G, C}\right)\left(1-\tau^{P, C}\right)^{2}}\left(1-b_{C}\right)+\frac{\tau^{P, C} i^{B H}}{\left(1-\tau^{P, C}\right)^{2}} b_{C}>0, \\
& \text { N-Firm: } \quad \frac{d\left(F_{K}^{N}-\delta\right)}{d \tau^{P, N}}=\frac{r^{V}}{\left(1-\tau^{P, N}\right)^{2}}\left(1-b_{N}\right)+\frac{\tau^{P, N} i^{B H}}{\left(1-\tau^{P, N}\right)^{2}} b_{N}>0,
\end{aligned}
$$

we find that reducing the corporate income tax and the personal income tax, respectively, has a positive impact on investment, because in each case the cost of capital declines. ${ }^{30}$

The economic implication of a decrease in the corporate tax rate is straight-forward. If the corporate tax rate decreases, returns stemming from real investments are more heavily taxed compared to those from a financial investment which is not subject to the corporate tax rate. Hence, the cost of capital declines resulting in more real investments. The size of this effect will be larger for firms endowed with much equity and smaller for highly indebted firms.

\footnotetext{
${ }^{30}$ Since we also assume that the debt asset ratio is optimally chosen, a marginal change in a tax rate has no influence on the optimal debt asset ratio which enters the cost of capital formula.
} 


\section{$\mathrm{ACE}$}

In order to analyze the arising effects if we introduce an ACE/ACNE, we have to set both parameters $z_{1}$ and $z_{2}$ equal to one. Thus, the cost of capital formula in eq. (18) changes to:

$$
\begin{aligned}
& F_{K}^{f}-\delta=\left[\frac{r e^{f}}{\gamma^{D, f}}\left(\gamma^{I, f}-\Omega^{f} b^{f}\right)-\frac{\tau^{P, f}}{\theta^{P, f}}\left(1-b^{f}\right) i^{E}\right]+\left[i^{B H}+m^{f}\right] b^{f} \\
& \text { C-Firm: } \quad F_{K}^{C}-\delta= {\left[\frac{{ }^{V^{C}}}{\theta^{P, C} \theta^{G, C}}-\frac{\tau^{P, C}}{\theta^{P, C}} i^{E}\right]\left(1-b_{C}\right)+\beta \frac{{ }^{V^{C}}}{\theta^{P, C} \theta^{G, C}}\left[\frac{\theta^{G, C}}{\theta^{D, C}}-1\right] } \\
&+\left(i^{B H}+m_{C}\right) b_{C}-z_{3} \tau^{P, C} \frac{r^{V}{ }^{C}}{\theta^{P, C} \theta^{G, C}}\left[1+\beta\left(\frac{\theta^{G, C}}{\theta^{D, C}}-1\right)\right], \\
& N \text {-Firm: } \quad F_{K}^{N}-\delta= {\left[\frac{r^{V^{N}}}{\theta^{P, N}}-\frac{\tau^{P, f}}{\theta^{P, N}} i^{E}\right]\left(1-b^{N}\right)+\left(i^{B H}+m^{N}\right) b^{N} } \\
&-z_{3} \tau^{P, N} \frac{r^{V^{N}}}{\theta^{P, N} \theta^{G, N} .}
\end{aligned}
$$

Accordingly, the cost of capital for each type of firm declines by the amount $\frac{\tau^{P, f}}{\theta^{P, f}}\left(1-b_{f}\right) i^{E}$ if an $\mathrm{ACE} / \mathrm{ACNE}$ is considered. In Figure 5 the optimal capital stock is again given by the intersection of the downward sloping marginal product curve with the horizontal cost of capital line. In case we introduce an ACE/ACNE, the cost of capital line shifts downwards.

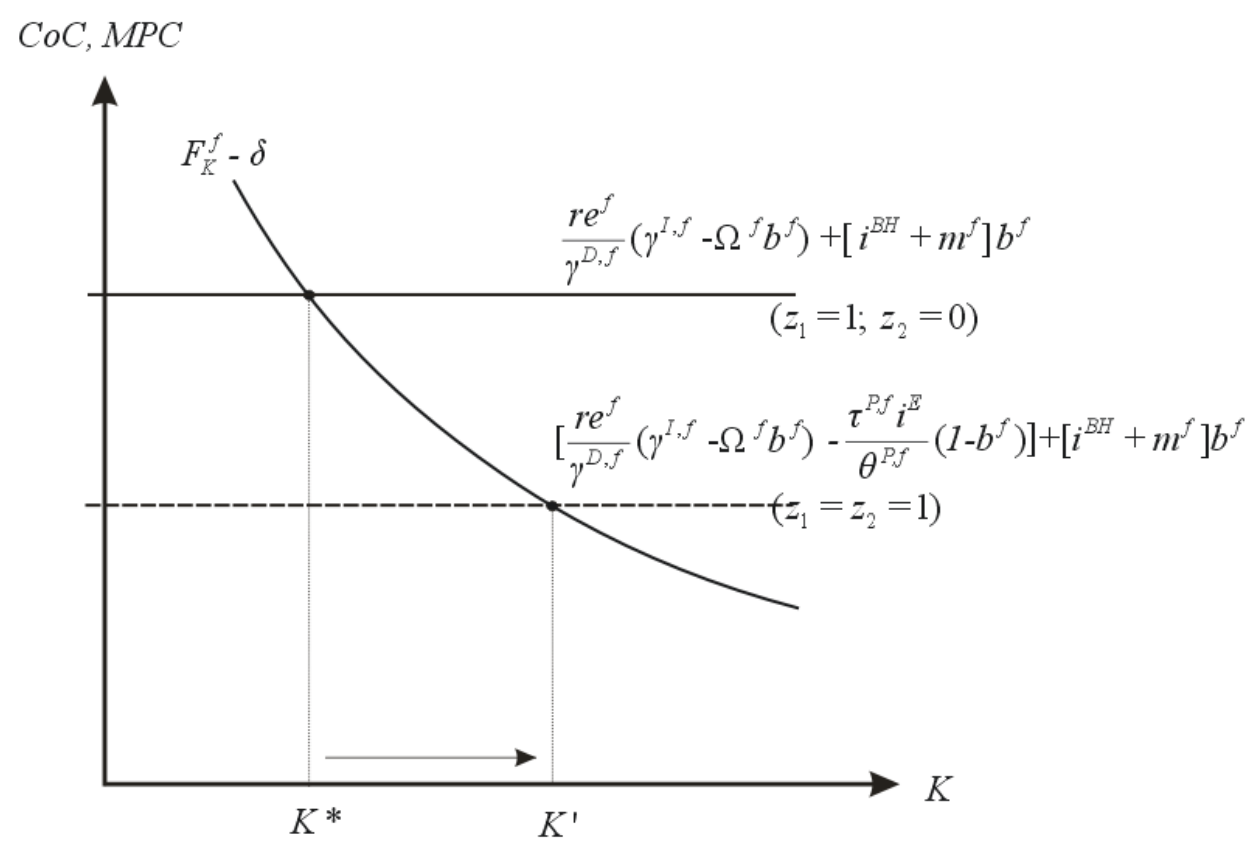

Capital Accumulation under the ACE/ACNE 
Therefore, under the ACE/ACNE the minimal required return an investment project has to earn declines implying that an increasing number of profitable investments are available. Consequently, capital accumulates and we will end up with a larger total stock of capital of $K^{\prime}$ in the economy.

For the comparative static analysis we again disregard external equity as a source of finance as well the possibility of an immediate write-off, implying $\beta=0$ and $z_{3}^{f}=0$.

Differentiating the cost of capital formulae given in (25) with respect to the corporate and personal income tax rate we get the same results as under the CBIT proposal ${ }^{31}$ :

$$
\begin{aligned}
& \text { C-Firm: } \quad \frac{d\left(F_{K}^{C}-\delta\right)}{d \tau^{P, C}}=\frac{r^{V^{C}}}{\left(1-\tau^{G, C}\right)\left(1-\tau^{P, C}\right)^{2}}\left(1-b_{C}\right)-\frac{i^{E}}{\left(1-\tau^{P, C}\right)^{2}}\left(1-b_{C}\right)>0, \\
& N \text {-Firm: } \quad \frac{d\left(F_{K}^{N}-\delta\right)}{d \tau^{P, N}}=\frac{r^{V^{N}}}{\left(1-\tau^{P, N}\right)^{2}}\left(1-b_{N}\right)-\frac{i^{E}}{\left(1-\tau^{P, N}\right)^{2}}\left(1-b_{N}\right)>0 .
\end{aligned}
$$

An increase in the corporate or personal income tax rate increases the cost of capital for the respective firm, while a reduction of these tax rates results in a decline in the firm specific cost of capital.

Moreover, under an ACE type of tax system, the cost of capital crucially depends on the size of the imputed interest.

$$
A C E: \frac{d\left(F_{K}^{C}-\delta\right)}{d i^{E}}=-\frac{\tau^{P, C}}{\theta^{P, C}}\left(1-b_{C}\right)<0
$$

According to the above equation, the higher the chosen imputed rate on equity capital, the lower the cost of capital will be due to the narrower tax base.

The remaining buildings blocks of a CGE model, in particular the household as well as the rest of the world, are not considered in detail here, since they are only of minor importance for the theoretical underpinning or the interpretation of the simulation results. The model documentation is completed by the government sector to show in which way the CBIT and the ACE/ACNE affects government revenues.

\footnotetext{
${ }^{31}$ For the ACE/ACNE we assume that $\mathrm{r}^{V}>i^{E}$ such that the imputed return is lower than the net return on equity (assumed here to be eight per cent).
} 


\subsection{Public Accounts}

The government collects revenue from taxing corporate and non-corporate firms, dividend, interest and labor income as well as capital gains and consumption. Total governmental tax revenue $T T R_{t}$ is therefore given by:

$$
T T R_{t}=\sum T^{P, f}+T^{D}+T^{I}+T^{L}+T^{G}+T^{C}
$$

with

$$
\begin{aligned}
& T^{P}= \sum \tau^{P, f}\left[Y^{f}-J^{f}-w^{f} L^{f}-\delta K^{f}-m^{f} B^{f}\right. \\
&\left.-z_{1} i^{B H} B^{f}-z_{2} i^{E}\left(K^{f}-B^{f}\right)-z_{3} I N^{f}\right], \\
& T^{i}=\tau^{i}\left[i^{B H} A^{B, H}+i^{H} A^{D H, H}+i^{F} A^{D F, H}\right] .
\end{aligned}
$$

Business income taxes, $T^{P}$, consist of corporate and personal income tax of domestic corporate and non-corporate firms $T^{P, C}+T^{P, N}$. In case $z_{1}$ and $z_{2}$ are set equal to one, so when both debt interest and the imputed return on equity are tax deductible, the profit tax base will shrink and accordingly also government revenues.

Moreover, firms pay interest on debt plus an agency cost $\left(i^{B H}+m^{f}\right) B^{f}$ while private households just receive the gross interest on debt, namely $i^{B H} A^{B, H}$. Taxable interest income is taxed at rate $\tau^{i}$ and the corresponding interest tax base comprises interest income on domestic firm bonds $A^{B, H}$ as well as on domestic and foreign government bonds, $A^{D H, H}$ and $A^{D F, H}$. The variables $i^{H}$ and $i^{F}$ denote the gross interest on domestic and foreign government bonds. Under the ACE/ACNE, the imputed return on equity capital is not taxed separately on the household level. However, earnings on firm shares are, depending on the scenario, subject to the dividend and capital gains tax.

The accumulation of public debt has to cover public consumption $C_{t}^{G}$, the primary deficit and the interest spending on public debt $\left(1+i^{H}\right) D_{t}^{G}$. The primary deficit is defined as the difference between lump-sum transfers $T_{t}^{H}$ and total tax revenue $T T R_{t}$.

$$
G D_{t+1}^{G}=\left(1+i^{H}\right) D_{t}^{G}+C_{t}^{G}+T_{t}^{H}-T T R_{t}
$$


The government debt accumulation is intertemporally constrained. It rules out expenditure increases to finance a budget deficit. A present imbalance has to be offset by a future compensating action.

\section{Simulation Results}

This Section presents and interprets the simulation results. Starting from the present German tax system we perform a number of simulations which depict either the introduction of an ACE/ACNE or of a CBIT. Revenue neutrality is assured either by a change in the VAT or in the profit tax. The scenarios can be ranked in the following way: the best results are achieved when the CBIT is accompanied by an immediate write-off and revenue neutrality is achieved by an exogenous change in the profit tax. When the VAT is adjusted to make sure that the government budget is balanced, the ACE/ACNE with no additional capital gains taxation leads to the most significant welfare gains.

Tables 1a and b summarize the status quo tax rates in Germany as well as the main behavioral parameters applied in the calibration. These parameter values are all confirmed by empirical findings in the literature (see the references in brackets).

\begin{tabular}{lc} 
Table 1a: Statutory German & Tax Rates (in \%) \\
\hline \hline Profit Tax, $\tau^{P, C} / \tau^{P, N C}$ & $0.383 / 0.454$ \\
Tax on Interest Income, $\tau^{i}$ & 0.443 \\
Dividend Income Tax, $\tau^{D}$ & 0.221 \\
Capital Gains Tax, $\tau^{G}$ & 0.00 \\
Labor Income Tax, $\tau^{L}$ & 0.295 \\
VAT, $\tau^{C}$ & 0.16 \\
\hline
\end{tabular}

Source: German Ministry of Finance, own calculations. 
Table 1b: Behavioral Parameters

\begin{tabular}{lc}
\hline \hline Economic Depreciation Rate & 0.1 \\
Intertemporal Elasticity of Substitution $\quad$ (FLAIG 1988) & 0.4 \\
Elasticity of Debt-Asset Ratio ${ }^{a} \quad \quad$ (GORDON and LEE 2001) & 0.36 \\
Elasticity of Factor Substitution (GERMAN CENTRAL BANK 1995) & 0.8 \\
Labor supply elasticity $\quad$ (weighted average of FENGE et al. 2002) & 0.37 \\
\hline$a)$ Elasticity with respect to the profit tax. & \\
\hline \hline
\end{tabular}

In the German tax system prevailing in 2004, the statutory corporate tax rate amounts to 25 per cent. Accounting also for the local trade tax and the solidarity surcharge, however, the effective corporate tax rate adds up to 38.3 per cent. On the household level, theoretically all types of income, including capital and labor income are merged and then taxed at a single progressive personal income tax rate which reaches a top marginal tax rate of 42 per cent, or 44.3 per cent if we include the solidarity surcharge. ${ }^{32}$ In Germany, different kinds of capital income including dividends and capital gains face, however, a specific tax treatment: Dividends are taxed according to the "half income principle" 33 , implying a lower tax burden on dividend income and capital gains are completely tax exempt.

The top personal income tax rate of 44.3 per cent just applies to interest income. Regarding labour income taxation, we assume an average annual labor income of $€ 20,814$ for the representative individual which translates into an average labor income tax rate of 28 per cent, or 29.5 per cent if we add the solidarity surcharge.

\footnotetext{
${ }^{32}$ The income tax rate applying to non-corporate firms is 45.4 per cent since it also includes part of the local trade tax.

${ }^{33}$ According to the German system of half imputation, only half of dividend payouts enter the tax base when computing the personal income tax liability. Our modelling approach for this dividend tax treatment, is to subject overall dividend income but only to half of the personal income tax rate.
} 
Table 2: Long Run Key Economic Figures (in \%)\#)

\begin{tabular}{lccc|cc}
\hline \hline & \multicolumn{3}{c|}{ ACE/ACNE } & \multicolumn{2}{c}{ CBIT } \\
\hline GDP & Sc.1 & Sc.2 & Sc.3 & z3=0 & z3=1 \\
\hline Capital Stock & 9.1 & 2.9 & 2.2 & -5.3 & 8.2 \\
Labor Supply & 20.5 & 9.6 & 8.4 & -10.2 & 16.2 \\
Disposable Income & 1.7 & -0.5 & -1.1 & -1.4 & 3.1 \\
Domestic Consumption & 6.5 & 5.3 & 5.6 & -4.3 & 4.8 \\
Change in VAT \%-points & 4.6 & -0.7 & -0.3 & -4.7 & 1.7 \\
Welfare in \% of Tot. Wealth & 0.1 & -1.1 & -1.4 & -1.2 & 0.06 \\
Welfare in \% of GDP & 0.08 & -0.6 & -0.8 & -0.7 & 0.04 \\
\hline
\end{tabular}

\#) Revenue neutrality via change in VAT; ${ }^{*)} \mathrm{z} 3=1$ stands for immediate write-off. Sc. $1: \operatorname{tg}=0 \%, \operatorname{td}=22 \%$;

Sc. $2: \operatorname{tg}=22 \%, \operatorname{td}=44 \%$; Sc. $3: \operatorname{tg}=\operatorname{td}=22 \%$. Source: Own calculations.

Table 2 depicts the first simulation results assuming that revenue neutrality is achieved via an adjustment in the VAT rate. We assume the imputed return on equity equals debt interest of six per cent to ensure neutrality with respect to the source of finance. Moreover, we run three different simulation scenarios with respect to introducing an ACE/ACNE. Scenario 1 assumes just the ACE/ACNE is introduced and only addresses the problem of financial neutrality at firm level. The taxation at personal level remains unchanged, implying a zero tax on capital gains and a tax of around 22 per cent on dividend income. However, under such a reform, interest income is still taxed on the personal level at the personal income tax rate. Therefore, to ensure there is no bias in investing in firm shares vis-à-vis firm bonds, both types of earnings have to be treated in similar ways on personal level. This is why Scenarios 2 and 3 apply in addition a capital gains tax of 22 per cent. ${ }^{34}$ In Scenario 2 the dividend tax equals the tax on interest income of 44.3 per cent while in Scenario 3 the half-income principle still holds, meaning that the dividend tax equals 22 per cent. For the CBIT reform proposal, we also consider two alternatives. The first

\footnotetext{
${ }^{34}$ Since capital gains are only taxable upon realization and not upon accrual only half of the personal income tax rate is taken as a rule of thumb in the simulation exercise
} 
case regards solely the introduction of a CBIT as usually stipulated in the literature. However, to ensure investment neutrality, one can also design a reform which in addition to the CBIT introduces provisions for immediate write-off. This situation is depicted in the last column of Table 2.

As opposed to the usual assumptions made in the literature, we do not apply for these first simulations an adjustment in the profit tax to ensure revenue neutrality since there are also other taxes at hand, such as the consumption tax, which can be increased (decreased) in case the tax revenue shrinks (rises) after the policy shock.

From Table 2 we can see that, given the present tax constellation, introducing an allowance for both corporate and non-corporate equity accompanied by the half-income principle of dividend taxation on household side achieves the best results. Due to the possibility to deduct an imputed return from the profit tax base the cost of capital decreases and accordingly investments and capital accumulation rise. The capital stock increases by around 20 per cent for the whole economy inducing an increase in labour demand of corporate firms by five per cent and an increase in aggregate labour supply of 1.7 per cent. The results are driven by the reduction in the cost of capital which decreases by 6.3 per cent and 4.3 per cent for the corporate and non-corporate sector respectively (see Table 3a). Since this reform scenario is rather costly, the VAT has to be increased in the long-run SS by nearly five percentage points to to ensure revenue neutrality. Thus, the positive welfare effects induced by the increased capital accumulation and labour demand are counterbalanced by the rather large increase in the VAT. Therefore, overall welfare rises by only 0.1 per cent in terms of life-time wealth.

The second best alternative is the CBIT combined with a provision for immediate write-off. Even though the cost of capital decline under this constellation turns out very large, the non-corporate sector faces a capital decumulation. The large demand for capital by the corporate sector following the drastic cost of capital reduction by almost 39 per cent combined with the sheer size of the corporate sector crowds out investments by the non-corporate sector. Thus, the overall increase in the capital stock of 16 per cent will be smaller compared to ACE/ACNE Scenario 1. Accordingly, the welfare effects turn out 
less positive as well even though the reform raises more revenue from the profit tax such that the VAT can even be lowered by 2.4 percentage points in the long-run SS (see Table $2)$.

The comparison of these two reform scenarios raises the question whether the positive results arise due to a shift of the tax burden via the VAT to the less elastic labour supply. This is one possible explanation, however, we have to keep in mind that on the one hand the VAT just distorts the labour-leisure decision by affecting current real wages. On the other hand, the profit tax or the interest income tax are more harmful for the economy. A high corporate tax leads in a world of high capital mobility to capital flight, to decreasing capital intensity and a resulting decline in the marginal productivity of labour. Domestic real wages go down such that in the end the burden of the corporate tax is finally borne by labour. All these implicit negative effects can thus be avoided if the tax burden is shifted from the corporate to the consumption tax.

Table 3a: Change in the Cost of Capital and the EMTR

\begin{tabular}{ccc|cc}
\hline \hline & \multicolumn{2}{c|}{ ACE/ACNE } & \multicolumn{2}{c}{ CBIT } \\
\hline & C-Firm & N-Firm & C-Firm & N-Firm \\
\hline Cost of Cap. (pre/post reform) & $10.6 / 9.9$ & $9.9 / 9.5$ & $10.6 / 11.6$ & $9.9 / 12.0$ \\
$\%$ - age Change & -6.3 & -4.3 & 9.7 & 21.8 \\
EMTR (pre/post reform) & $35.5 / 30.1$ & $37.0 / 31.8$ & $35.5 / 42.4$ & $37.0 / 50.0$ \\
$\%$ - age Change & -15.5 & -14.2 & 19.3 & 35.0 \\
Capital Stock (in \%) & 25 & 12.6 & 2.7 & -33.3 \\
Labor Demand (in \%) & 5 & -4.3 & 11.1 & -24.7 \\
\hline Source: Own calculations.
\end{tabular}


Table 3b: Change in the Cost of Capital and the EMTR

\begin{tabular}{ccc|cc|cc}
\hline \hline & \multicolumn{3}{c|}{ ACE/ACNE } & \multicolumn{2}{c}{ CBIT } \\
\hline & \multicolumn{2}{c}{ Sc.2 } & \multicolumn{2}{c}{ Sc.3 } & \multicolumn{2}{c}{ z3=1 } \\
& C-Firm & N-Firm & C-Firm & N-Firm & C-Firm & N-Firn \\
\hline Cap. Cost (pre/post reform) & $10.6 / 12.1$ & $9.9 / 9.4$ & $10.6 / 12.3$ & $9.9 / 9.6$ & $10.6 / 8.4$ & $9.9 / 9$. \\
\% - age Change & 14.4 & -4.5 & 16.0 & -3.0 & -21.0 & -4.7 \\
EMTR (pre/post reform) & $35.5 / 42.6$ & $37.0 / 30.1$ & $35.5 / 43.2$ & $37.0 / 32.9$ & $35.5 / 21.8$ & $37.0 / 3$ \\
\% - age Change & 19.7 & -17.7 & 21.5 & -11.1 & -38.8 & -17.6 \\
Capital Stock (in \%) & -21.4 & 65.1 & -22.2 & 63.5 & 41.5 & -29.2 \\
Labor Demand (in \%) & -25.1 & 45.3 & -25.6 & 44.5 & 23.0 & -33.9 \\
\hline
\end{tabular}

Source: Own calculations.

The above Tables also depict the results for implementing ACE/ACNE Scenarios 2 and 3. Under these scenarios the cost of capital for non-corporate firms declines, however, due to the introduction of a capital gains tax of 22 per cent, investments financed by retained earnings are negatively affected and thus the cost of capital for corporate firms increases (see Table 3b). ${ }^{35}$ Therefore, as shown in Table 3a, even though capital accumulates within the non-corporate sector, the economy-wide increase in the capital stock will only amount to 9.6 and 8.4 per cent respectively. Thus, the negative effects of the capital gains and the dividend tax will demand an even larger increase in the VAT by 6.5 and 8.4 percentage points respectively to ensure the government budget is balanced. Thus, labour supply will decline and accordingly also domestic consumption leading to a decrease in welfare in per cent of total wealth by 1.1 per cent in Scenario 2 and by 1.4 per cent in Scenario 3 .

The pure CBIT which is not accompanied by a provision for immediate write-off does not produce favorable results either. Since the advantage of debt interest deductibility does not apply anymore, the cost of capital increases by around 10 per cent for corporate firms and by around 22 per cent for non-corporate ones. As a result, the capital stock decumulates for the entire economy by ten per cent. Thus, GDP also shrinks by 5.3 per cent, labour demand declines and accordingly gross wages and consumption. Therefore,

\footnotetext{
${ }^{35}$ Remember that non-corporate firms can not rely on retained earnings as a source of finance and can just draw on external dbt and new share issues to finance new investments.
} 
this reform even induces a decline in welfare by 1.2 per cent in terms of life-time income or 0.7 per cent of GDP. This negative outcome occurs even though as a result of the increased profit tax revenue, a lower VAT of namely 14.7 per cent compared to the former 16 per cent is sufficient to ensure revenue neutrality. The negative impact on the accumulation of capital and accordingly on gross wages (assuming the same profit tax rate prevails after the reform as well) is so large that it can not be compensated by a lower consumption tax. Once again the harmful consequences of profit taxation compared to the rather modest positive effects triggered by lower consumption taxation are striking.

The simulation which envisages the introduction an ACE/ACNE financed by an exogenous increase in the profit tax rate shows that this rate can not be high enough to compensate for the costs of the reform since even at very large values transfers to households still decrease. ${ }^{36}$ This result occurs since our dynamic general equilibrium model captures a wide range of effects and economy-wide repercussions and a high profit tax rate will have a substantial negative effect on investments, capital accumulation, GDP and labour demand thus shrinking the tax base of the other taxes as well and requiring an adjustment in transfers to finance such a reform. If we performed our analysis in a two-period framework, in which only the second period budget needs to be balanced, the simulations show that the introduction of the ACE/ACNE Scenario 1 needs to be accompanied either by an increase in the corporate tax rate to 53.5 per cent so by 15.2 percentage points or by a simultaneous increase in the tax rate on corporate profits from 38.3 to 46.5 per cent and in the tax rate on non-corporate profits from 45.4 to 54.5 per cent other things being equal.

In case a CBIT without immediate write-off is implemented in a two period framework, the possible reduction in tax rates which assure in the second period a balanced budget is tremendous. A reduction of namely almost ten percentage points in both tax rates, leading to a corporate tax of 27.5 per cent and a tax on non-corporate profits of 35.5 per cent leads to the same overall tax revenue as before. The same balanced budget is achieved if just the corporate tax rate is reduced to 20.5 per cent other things being equal. Nevertheless,

\footnotetext{
${ }^{36}$ In case the VAT rate is kept constant, the government budget is balanced via a change in the lumpsum transfers to households.
} 
once again such a computation neglects the economy-wide repercussions which can be captured by our dynamic general equilibrium model. The strength of this model consists in exactly this particular computation and evaluation of the overall effects of a tax reform.

Finally, the last simulations performed take into account this time an exogenous adjustment in the corporate tax as a means to ensure revenue neutrality. Therefore, a uniform tax of 38 (30) per cent on non-corporate and corporate profits is required to balance the public sector budget in case the CBIT is introduced without (with) immediate write-off. Removing the advantage of debt interest deductibility accompanied by a reduced profit tax rate brings about the following results:

Table 4: Long Run Key Economic Figures (in \%)

\begin{tabular}{|c|c|c|c|c|c|c|}
\hline & \multicolumn{6}{|c|}{ CBIT } \\
\hline & \multicolumn{3}{|c|}{$\mathbf{z} 3=\mathbf{0}^{\#)}$} & \multicolumn{3}{|c|}{$\mathrm{z} 3=\mathbf{1}^{*)}$} \\
\hline & Total & C-Firm & N-Firm & Total & C-Firm & N-Firm \\
\hline Cost of Cap.(pre/post reform) & & $10.6 / 11.8$ & $9.9 / 6.1$ & & $10.6 / 8.1$ & $9.9 / 8.4$ \\
\hline$\%$ - age Change & & 11.4 & -38.4 & & -23.5 & -15.0 \\
\hline EMTR (pre/post reform) & & $35.5 / 42.7$ & $37.0 /-0.8$ & & $35.5 / 16.3$ & $37.0 / 21.3$ \\
\hline$\%$ - age Change & & 20.3 & -100.0 & & -54.2 & -42.4 \\
\hline GDP & -4.9 & & & 9.7 & & \\
\hline Capital Stock & -8.9 & -9.9 & -7.3 & 20.1 & 35.5 & -7.7 \\
\hline Labor Demand & -1.6 & -2.5 & -0.04 & 3.0 & 14.7 & -18.6 \\
\hline Disposable Income & -3.2 & & & 7.1 & & \\
\hline Domestic Consumption & -4.9 & & & 4.6 & & \\
\hline Welfare in $\%$ of Total Wealth & -1.3 & & & 0.3 & & \\
\hline Welfare in $\%$ of GDP & -0.8 & & & 0.2 & & \\
\hline
\end{tabular}

Of course, these results may change if a CBIT is accompanied c.p. by a reduction in the corporate tax or in the tax rate on non-corporate profits solely.

The first three columns of Table 4 show the results of implementing a pure CBIT without any special depreciation allowances. The overall message is clear: Even though 
the usual line presented in the literature states that a CBIT might have positive effects because of the lower profit tax rates which apply and which constitute a positive signal for investors, the simulation results show that the overall effect on the cost of capital for corporate firms is negative since the post-reform uniform profit tax which ensures revenue neutrality is still rather high. The new tax level is however lower for the noncorporate sector such that firms belonging to this sector face a cost of capital decline. Nevertheless, the overall capital stock declines in the long-run since the corporate sector is the key driving force due to its considerably larger size. The picture changes when we allow for immediate write-off. In this case, as shown in columns 4-6 in Table 4, there is a tremendous decline in capital costs which leads to an increase in capital accumulation. The long-run SS capital stock increases by 20 per cent, leading to an increase in labour demand by three per cent. As a result wages will rise and accordingly also disposable income and consumption. Therefore, the increase in welfare of 0.3 per cent in terms of total wealth is even higher than in case the ACE Scenario 1 financed by an increase in the VAT (see Table 2).

\section{Sensitivity Analysis}

Lastly, Section 4 presents the sensitivity analysis which, as in all types of simulations performed with dynamic CGE models, is of crucial importance. In our case, it is among other things, the debt asset ratio, the corporate tax rate and the imputed return on equity which influence our results and which in the following will be considered in more detail.

Thus, given the above effects, it is interesting to see how such policy shocks affect economic aggregates if we start from a comparatively lower tax rate instead of the present corporate tax rate of 38.3 per cent on corporate profits. Such an experiment is of interest for countries like the new EU Member States which are characterized by much lower corporate tax rates and for which accordingly different reform scenarios might be appealing. 
Table 5: Long Run Key Economic Figures (in \%)\#)

\begin{tabular}{lccc|cc}
\hline \hline & \multicolumn{3}{c|}{ ACE/ACNE } & \multicolumn{2}{c}{ CBIT } \\
\hline GDP & Sc.1 & Sc.2 & Sc.3 & z3=0 & z3=1 \\
\hline Capital Stock & 5.5 & 0.7 & 0.5 & -3.9 & 5.0 \\
Labor Supply & 12.9 & 4.5 & 4.2 & -6.5 & 9.9 \\
Disposable Income & 0.6 & -1.2 & -1.5 & -1.0 & 2.0 \\
Domestic Consumption & 6.8 & 3.8 & 4.2 & -3.1 & 3.0 \\
Change in VAT \%-points & 2.9 & -2.9 & -1.9 & -3.4 & -0.5 \\
Welfare in \% of Tot. Wealth & -0.5 & -1.1 & -1.2 & -1.1 & -0.4 \\
Welfare in \% of GDP & -0.3 & -0.7 & -0.7 & -0.6 & -0.2 \\
\hline \#) Revenue neutrality via change in VAT; reduced profit tax of $25 \% ;$ \\
*) z3=1 stands for immediate write-off. Sc.1: tg=0\%, td=22\%; \\
Sc.2: tg=22\%,td=44\%; Sc.3: tg=td=22\% . Source: Own calculations. \\
\hline \hline
\end{tabular}

For instance, starting from an overall statutory tax rate on corporate profits of 25 per cent the picture changes as depicted in Tables 5, 6a and 6b. In this case, even under an ACE/ACNE Scenario 1 welfare decreases by around 0.3 per cent of GDP because the additional advantage of being able to deduct an imputed return from the profit tax base (which is now lower than in case we start from a higher profit tax) is more than offset by the disadvantage of the higher VAT of 21.5 per cent required to finance the reform. The increase in the corporate sector cost of capital is now even larger under Scenarios 2 and 3 such that the increase long-run capital accumulation of 4.5 and 4.2 per cent respectively is more modest than before. Thus, it is not astonishing that the even larger increase in the VAT needed to finance the reform will in the end trigger considerable losses in welfare (see Table 5). 
Table 6a: Change in the Cost of Capital and the EMTR

\begin{tabular}{ccc|cc|c|c}
\hline \hline & \multicolumn{3}{c}{ ACE/ACNE } \\
\cline { 2 - 7 } & \multicolumn{2}{c}{ Sc.1 } & \multicolumn{2}{c}{ Sc.2 } & \multicolumn{2}{c}{ Sc.3 } \\
\hline & C-Firm & N-Firm & C-Firm & N-Firm & C-Firm & N-Firn \\
\hline Cap. Cost (pre/post reform) & $9.1 / 8.9$ & $9.9 / 9.4$ & $9.1 / 10.8$ & $9.9 / 9.4$ & $9.1 / 10.7$ & $9.9 / 9$. \\
\% - age Change & -2.6 & -4.7 & 18.4 & -4.7 & 17.6 & -3.4 \\
EMTR (pre / post reform) & $25.1 / 21.7$ & $37.0 / 31.3$ & $25.1 / 35.4$ & $37.0 / 30.2$ & $25.1 / 34.9$ & $37.0 / 30$ \\
\% - age Change & -13.4 & -15.5 & 41.2 & -18.6 & 39.0 & -12.9 \\
Capital Stock (in \%) & -2 & 41.5 & -39.4 & 89.4 & -37.2 & 84.2 \\
Labor Demand (in \%) & -11.4 & 22.9 & -39.0 & 69.0 & -37.1 & 64.6 \\
\hline
\end{tabular}

Source: Own calculations.

Table 6b: Change in the Cost of Capital and the EMTR

\begin{tabular}{c|cc|cc}
\hline \hline \multirow{2}{*}{} & \multicolumn{4}{|c}{ CBIT } \\
\cline { 2 - 5 } & \multicolumn{2}{|c|}{$\mathbf{z 3 = 0}$} & \multicolumn{2}{c}{$\mathbf{z 3 = 1}$} \\
\cline { 2 - 5 } & C-Firm & N-Firm & C-Firm & N-Firm \\
\hline Cost of Capital (pre / post reform) & $9.1 / 9.6$ & $9.9 / 12.0$ & $9.1 / 8.0$ & $9.9 / 9.0$ \\
$\%$ - age Change & 5.0 & 21.5 & -11.9 & -9.0 \\
EMTR (pre / post reform) & $25.1 / 29.8$ & $37.0 / 49.8$ & $25.1 / 16.6$ & $37.0 / 26.9$ \\
\% - age Change & 18.7 & 34.5 & -33.7 & -27.5 \\
Capital Stock (in \%) & 11.0 & -40.2 & 13.3 & 3.2 \\
Labor Demand (in \%) & 16.4 & -33.4 & 4.9 & -3.5 \\
\hline
\end{tabular}

Source: Own calculations.

As shown in Tables 5 and 6b, the CBIT with no immediate write-off the leads under the new tax constellation to slightly better results than in the base scenario. As we start from a lower corporate tax, the disadvantage from the lack of debt interest deductibility is now less severe. The cost of capital increases by about 5 and 21 per cent respectively for corporate and non-corporate firms inducing a decline in the overall capital stock of 6.5 per cent (see Table 5). Gross wages and thus disposable income and consumption decline resulting in a decrease in welfare by 0.6 per cent in terms of GDP. If the CBIT is 
implemented in combination with a provision for immediate write-off, the increase in tax revenue is not as large as in the reform scenario starting from a 38 per cent profit tax. Thus, the long-run SS VAT tax can only be reduced by 1.6 percentage points (see Table 5 ) and thus the reform leads to an overall slight welfare loss of 0.2 per cent in terms of GDP.

An additional question to be asked is what happens in case the imputed return differs from the interest rate paid on debt, such that neutrality with respect to the source of finance is not guaranteed anymore. For the sensitivity analysis we assume this presumptive return equals the risk-free interest rate on government debt of three per cent, thus being lower than the interest paid on firm debt. Taking the ACE/ACNE Scenario 1 where no tax on capital gains applies as an example, the results change in the following way:

Table 7: Long Run Key Economic Figures (in \%)

\begin{tabular}{lc|cc}
\hline \hline ACE/ACNE Sc.1 ${ }^{\#)}$ & Total & C-Firm & N-Firm \\
\hline Cost of Capital (pre/post reform) & & $10.6 / 9.6$ & $9.9 / 9.0$ \\
$\quad \%$ - age Change & & -9.3 & -8.7 \\
EMTR (pre/post reform) & & $35.5 / 28.5$ & $37.0 / 30.1$ \\
$\quad \%$ - age Change & 3.4 & & -18.8 \\
\hline GDP & 7.5 & 8.9 & 5.0 \\
Capital Stock & 0.7 & 1.9 & -1.4 \\
Labor Demand & 3.4 & & \\
Disposable Income & 2.6 & & \\
Domestic Consumption & 1.7 & & \\
Increase in VAT \%-points & & \\
Welfare in \% of Total Wealth / GDP & $0.3 / 0.1$ & \\
\hline \#) revenue neutrality via change in VAT; imputed return < interest rate on debt; \\
Source: Own calculations. \\
\hline \hline
\end{tabular}

Even though this alternative does not equalize the cost of capital across the different sources of finance, the overall induced macroeconomic effects are higher than in the previous case (see Table 3). As a lower return is deducted from the tax base, the revenue 
loss turns out to be smaller. Therefore, the required increase in the VAT rate to balance the government budget is lower, thus leading to slightly higher welfare results. ${ }^{37}$

Finally, a last sensitivity analysis is performed with respect to the debt asset ratio. This parameter is of particular importance for the CBIT reform alternative because it influences the effects of such a reform to a large extent. Accordingly, in some countries firms which are characterized by a lower debt asset ratio suffer less from such a reform since the lost advantage of debt interest deductibility is less considerable. Table 8 summarizes the results of the sensitivity analysis which accounts for a debt asset ratio of only 18 per cent for corporate firms and 27.5 per cent for non-corporate firms, thus one half of the debt asset ratios used in the base case. We assume the reform is financed by a change in the VAT.

Table 8: Long Run Key Economic Figures (in \%)\#)

\begin{tabular}{|c|c|c|c|c|c|c|}
\hline & \multicolumn{6}{|c|}{ CBIT } \\
\hline & \multicolumn{3}{|c|}{$\mathrm{z} 3=0$} & \multicolumn{3}{|c|}{$\mathrm{z} 3=1$} \\
\hline & Total & C-Firm & N-Firm & Total & C-Firm & N-Firm \\
\hline Cost of Cap. (pre/post reform) & & $10.6 / 12.5$ & $9.9 / 13.6$ & & $10.6 / 8.5$ & $9.9 / 9.3$ \\
\hline$\%$ - age Change & & 18.9 & 38.9 & & -18.8 & -5.2 \\
\hline EMTR (pre/post reform) & & $35.5 / 41.2$ & $37.0 / 48.1$ & & $35.5 / 15.8$ & $37.0 / 22.1$ \\
\hline$\%$ - age Change & & 17.2 & 32.1 & & -55.2 & -39.4 \\
\hline GDP & -3.7 & & & 15.4 & & \\
\hline Capital Stock & -6.5 & 0.9 & -20.5 & 30.9 & 37.8 & 17.7 \\
\hline Labor Demand & -1.3 & 5.8 & -14.5 & 5.8 & 10.9 & -3.7 \\
\hline Disposable Income & -2.3 & & & 8.9 & & \\
\hline Domestic Consumption & -4.1 & & & 10.2 & & \\
\hline Change in VAT \%-points & 0.7 & & & -5.0 & & \\
\hline Welfare in $\%$ of Total Wealth & -1.2 & & & 1.8 & & \\
\hline Welfare in $\%$ of GDP & -0.7 & & & 1.0 & & \\
\hline
\end{tabular}

Note: \#) revenue neutrality via change in VAT; Source: Own calculations.

\footnotetext{
${ }^{37}$ For the CBIT such a reform alternative does not influence the results since no imputed return on equity can be deducted.
} 
The first three columns of Table 8 depict the results for a CBIT without immediate write-off. Compared to the baseline simulation results presented in Table 2, the changes in most of the macroeconomic variables do not differ much. As shown in Table 8, the tax base broadening leads to less revenue than before since the debt asset ratio is now lower. Therefore, a slight increase in the VAT of 0.7 per cent is now required to balance the government budget. Nevertheless, the loss in welfare is as high as in Table 2. As opposed to this, if the CBIT is accompanied by a provision for immediate write-off, the reform produces even larger positive effects. The cost of not allowing for debt interest deductibility is now smaller and therefore the considerable capital accumulation of 15.4 per cent has positive effects on the whole economy. The reform leads to higher revenues from the taxation of corporate and non-corporate profits such that the long-run VAT can be even reduced by five percentage points. The overall welfare gain amounts to one per cent in terms of GDP.

\section{Conclusion}

The aim of this paper was to discuss two main reform alternatives of corporate income taxation. On the one hand, the ACE as suggested by the IFS Capital Taxes Group which provides for the reduction of an imputed return on equity from the profit tax base and on the other hand the CBIT that abolishes the preferential debt treatment by eliminating debt interest deductibility. Both policy scenarios align the cost of capital for investments financed by debt or equity. Under the ACE the tax base of the profit tax becomes narrower such that opponents of this reform argue a higher corporate tax rate is necessary to guarantee a certain tax revenue; this outcome is however, not desirable for a small open economy in a world of high capital mobility where the profit tax rate acts as a signalling device. Nevertheless, if we assume the reforms are financed by a change in the VAT rate and not in the profit tax rate, our simulation results show that introducing an $\mathrm{ACE} / \mathrm{ACNE}$ with no additional capital gains tax on personal level, has significant positive effects for investment, capital accumulation and welfare. For the opposite reform scenario,

the CBIT, the results turn out to be less favorable. Here, the cost of capital rises and 
induces negative consequences for investment. Firms will reduce their labour demand, gross wages will decrease and even though a lower VAT rate applies this is not enough to compensate the negative effects of the reform. However, if the CBIT is accompanied by a provision for immediate write-off to ensure investment neutrality, the effects of such a scenario are also positive. Moreover, if we allow for this second reform scenario for an exogenous adjustment in the profit tax instead of the VAT to finance the reform, the CBIT accompanied by immediate write-off achieves the best results. For the implementation of the ACE/ACNE, an exogenous increase in the profit tax is not high enough to finance such a reform in a dynamic general equilibrium framework since in every time period the $\mathrm{ACE} / \mathrm{ACNE}$ is deducted against the higher profit tax and therefore the deficit does not shrink at all. Additionally, the higher profit tax rates have negative effects on capital accumulation and thus on labor demand and on other macroeconomic variables. A rise in the profit tax rate solely is therefore insufficient due to these substantial negative economywide repercussions and needs to be accompanied either by a reduction in transfers or an increase in the VAT to ensure a balanced public sector budget.

Scenarios 2 and 3 of the ACE/ACNE in addition also implement a capital gains tax of 22 per cent on personal level to provide for a comparable treatment of the different types of capital income. This particular tax has negative effects on the cost of capital and thus on capital accumulation within the corporate sector. This results from our modelling approach. We implement namely the "New View" of dividend taxation. Accordingly, retentions are the marginal source of finance for investments in the corporate sector and thus a high capital gains tax will raise the cost of capital and lead to capital decumulation within this sector which accounts for $2 / 3$ of the economy's capital stock.

To avoid the double taxation of interest income under the CBIT reform proposal, one could envisage the abolishment of interest income taxation on household level. Nevertheless, under these circumstances, policy makers would have to think of whether to extend this generous treatment of interest income only to income received from domestic firm bonds or to domestic and foreign government bonds as well. Even though we do not quantify this last simulation exercise in this paper, the overall effects will depend on which of the two opposite effects will prevail. The positive effects of no interest income taxation 
face the negative effects of a higher VAT or a lower decline in the profit tax which might be necessary to compensate the revenue loss.

Finally, the sensitivity analysis underlines the accuracy which policy makers should put forward when designing a reform proposal. The outcome of the different scenarios are very sensitive with regard to the choice of the imputed return, the calibrated debt asset ratio or the corporate tax rate. Therefore, the magnitude of these parameters is crucial when deciding on one reform alternative or the other.

Overall, one can say that for the comparison and evaluation of these two diametrically opposite reform alternatives it is very important to consider additional issues besides the aspect of financial neutrality on firm level. If in addition, an ACE/ACNE reform scenario taxes capital gains and dividend on personal level as well, such that interest income and earnings from owning firm shares are treated in a similar way, or, if a provision for immediate write-off is also applied in case of a CBIT to ensure investment neutrality, the results may change to a large extent. Thus, the ultimate decision on which scenario is the best reform alternative depends on the concrete reform details and might also differ from country to country. Different nations apply at present different corporate tax rates, their firms are characterized by different debt asset ratios, the macroeconomic background differs from case to case and thus one can not make across-the board recommendations but understand that the most appropriate reform scenario depends on the given circumstances. 


\section{Appendix}

\section{A1 Corporate Firms}

Since we refer to a mature economy, characterized by mature firms ${ }^{38}$, we follow the 'New View' of dividend taxation. ${ }^{39}$ This is one approach used in the corporate finance literature to characterize the relationship between taxes and the cost of capital ${ }^{40}$. Accordingly, dividends $\operatorname{Div}^{C}$ are determined residually (SINN, 1987). The marginal source of finance will be retained earnings $\pi^{C}-D i v^{C}$ and the marginal use of funds, dividend payout. Therefore, since dividend taxes avoided today by financing investments via retained earnings can be set against as the future dividend tax payments, dividend taxes will not affect the cost of capital at all. Thus, dividend taxes are neutral with respect to the firm's financing decision.

Keeping in mind the empirical evidence provided by Auerbach And Hasset $(2003)^{41}$, who state that both views on the effects of dividend taxation are valid, we determine new share issues by $V N_{t}^{C}=\beta\left(1-z_{3} \tau^{P f}\right) I N_{t}^{C}$. This approach is similar to FEHR (1999). New investments are largely financed by retained earnings or by new debt $B N^{C}$ and only a fixed fraction, $\beta$, of five per cent is financed via new share issues. However, this approach does not apply to non-corporate firms, because these have to rely on external equity to finance investments

Plugging eq.(3) into the flow of funds equation, we derive an explicit expression for

\footnotetext{
38 According to the nucleus theory the nucleus is incorporated in the first step and then a phase of internal growth sets in. During this phase, no dividends are paid, nor are any new shares issued, but all profits are retained to finance profitable investments. After the nucleus has reached its stage of maturity, profits are distributed as dividends. The dividend tax discriminates against the initial size of the nucleus; thus in the set-up phase, the 'Old View' applies, but the dividend tax is neutral in the stage of maturity according to the 'New View' of dividend taxation (SINn 1991).

${ }^{39}$ This hypothesis on the effect of dividend taxation was developed among others by AUERBACH (1979), BRADFORD (1981) and SINN (1987). In contrast, the 'Old View' of dividend taxation assumes that shareholders prefer dividend distributions due to their so-called signalling function, because of a certain cash preference or since they desire to reduce managerial discretion over the use of profits. For a detailed discussion on the 'Old' and 'New View' of dividend taxation see also Sinn (1990), SøREnSEn (1995) and ZODROW (1991).

${ }^{40}$ The cost of capital is defined as the minimum pre-tax rate of return generated by an investment if it is to be undertaken.

${ }^{41}$ Further empirical evaluations of these two specifications were performed in an econometric study by Poterba and Summers (1983) and by applying a dynamic CGE model by Hutton and Kenc (1998).
} 
dividends $D i v^{C}$ as output $Y^{C}$ less labor costs $w^{C} L^{C}$, interest payments $i^{B H} B^{C}$, new shares $V N_{t}^{C}$, depreciation $\delta K^{C}$ and corporate tax payments:

$$
\begin{aligned}
\operatorname{Div}^{C} & =\theta^{P, C}\left[Y^{C}-J^{C}-m^{C} B^{C}-w^{C} L^{C}-\delta K^{C}\right]-\left(1-z_{1} \tau^{P, C}\right) i^{B H} B^{C} \\
& +B N^{C}+z_{2} \tau^{P, C} r K^{C}-z_{2} \tau^{P, C} r B^{C}-\left[(1-\beta)\left(1-z_{3} \tau^{P, C}\right)\right] I N^{C}
\end{aligned}
$$

Again, the precise constellation of the parameters $z_{1}$ and $z_{2}$ allow us to model the present German tax system or a reform proposal which introduces an ACE or a CBIT. In equilibrium, the return on equity has to equal the net of tax dividend payment and the net of tax capital gains which can be derived from holding firm shares. Hence

$$
\begin{aligned}
r_{t}^{V} V_{t}^{C} & =\theta^{D, C} \operatorname{Div}_{t}^{C}+\theta^{G, C}\left[G V_{t+1}^{C}-V_{t}^{C}-V N_{t}^{C}\right] \\
{[1+\underbrace{\left.\frac{r_{t}^{V}}{\theta^{G, C}}\right]}_{r e_{t}^{V C}} V_{t}^{C}} & =\underbrace{\frac{\theta^{D, C}}{\theta^{G, C}} D_{t}^{C}-V v^{C}}_{\chi_{t}^{C}}+G V_{t+1}^{C} .
\end{aligned}
$$

Here $r_{t}^{V}$ is the investor's required return that is necessary if the investor should be willing to hold the asset. This return is higher than the net return on firm or government bonds $\left(i^{B H}\right)$ since it includes a risk premium.

Introducing the two tax factors $\gamma^{D, C}=\frac{\theta^{D, C} \theta^{P, C}}{\theta^{G, C}}$ and $\gamma^{I, C}=\left[\frac{\theta^{D, C}}{\theta^{G, C}}(1-\beta)+\beta\right](1-$ $\left.z_{3} \tau^{P, C}\right)$ as well as $\Omega^{C}=\frac{\theta^{D, C}}{\theta^{G, C}}$, the formula for $\chi_{t}^{C}$ is given by:

$$
\begin{aligned}
\chi_{t}^{C} & =\gamma^{D, C}\left[Y^{C}-J^{C}-m^{C} B^{C}-w^{C} L^{C}-\delta K^{C}-\frac{\left(1-z_{1} \tau^{P, C}\right)}{\theta^{P, C}} i^{B H} B^{C}\right] \\
& +\Omega^{C} B N^{C}+\frac{\gamma^{D, C}}{\theta^{P, C}} z_{2} \tau^{P, C} r K^{C}-\frac{\gamma^{D, C}}{\theta^{P, C}} z_{2} \tau^{P, C} r B^{C}-\gamma^{I, C}\left(I^{C}-\delta K^{C}\right)
\end{aligned}
$$

\section{A2 Non-Corporate Firms}

As opposed to corporate firms, a non-corporate firm has no possibility to finance investments out of retained earnings, since all profits are distributed to the owner, implying $D i v^{N}=\pi^{N}$. This is true for they are considered as part of the entrepreneur's income as if these profits were distributed.

Therefore, a non-corporate firm can only choose between new debt, $B N^{N}$, and new 
equity injections, $V N^{N}$, as a possible source of finance for its investments but is not able to draw like a corporate firm on retentions.

The flow of funds equation for the non-corporate firm can be simplified to:

$$
V N^{N}=I N^{N}-B N^{N}
$$

The return on equity again equals dividends and net of tax capital gains:

$$
\begin{aligned}
& r_{t}^{V} V_{t}^{N}=\operatorname{Div}_{t}^{N}+\theta^{G, N}\left[G V_{t+1}^{N}-V_{t}^{N}-V N_{t}^{N}\right] . \\
& {[1+\underbrace{\frac{r_{t}^{V}}{\theta^{G, N}}}_{r e_{t}^{V N}} V_{t}^{N}=\underbrace{\frac{1}{\theta^{G, N}} \operatorname{Div} v_{t}^{N}-V N_{t}^{N}}_{\chi_{t}^{N}}+G V_{t+1}^{N},}
\end{aligned}
$$

Introducing once again the two tax factors $\gamma^{D, N}=\frac{\theta^{P, N}}{\theta^{G, N}}$ and $\gamma^{I, N}=1-\frac{\tau^{P, N} z_{3}}{\theta^{G, N}}$ as well as $\Omega^{N}=1$, the expression for $\chi_{t}^{N}$ is:

$$
\begin{aligned}
\chi^{N} & =\gamma^{D, N}\left[Y^{N}-J^{N}-m^{N} B^{N}-w^{N} L^{N}-\delta K^{N}-\frac{1-z_{1} \tau^{P, N}}{\theta^{P, N}} i^{B H} B^{N}\right] \\
& +\Omega^{N} B N^{N}+\frac{\gamma^{D, N}}{\theta^{P, N}} z_{2} \tau^{P, N} r K^{N}-\frac{\gamma^{D, N}}{\theta^{P, N}} z_{2} \tau^{P, N} r B^{N}-\gamma^{I, N}\left(I^{N}-\delta K^{N}\right) .
\end{aligned}
$$

\section{References}

[1] Auerbach, A.J. (1979), Wealth Maximization and the Cost of Capital, Quarterly Journal of Economics 93, pp. 433-446.

[2] Auerbach, A. J. and K. A. Hassett (2003), On the Marginal Source of Investment Funds, Journal of Public Economics 87, pp. 205-232.

[3] Boadway, R. and N. Bruce (1984), A General Proposition on the Design of a Neutral Business Tax, Journal of Public Economics 24, pp. 231-239

[4] Bond, S. R. (2000), Levelling up or levelling down? Some reflections on the ACE and CBIT proposals, and the future of the corporate tax rate, in Taxing Capital Income in the European Union, (ed.) S. Cnossen, Oxford University Press.

[5] Bond, S. and M. Devereux (1999), Generalized R-Based and S-Based Taxes under Uncertainty, IFS Working Paper No. W99

[6] Bradford, D.F. (1981), The Incidence and Allocation Effects of a Tax on Corporate Distributions, Journal of Public Economics 15, pp. 1-22. 
[7] Bruckner K., Gassner W., Riener-Micheler E. (2000), Steuerreform 2000/Eigenkapitalverzinsung, in: Institut Österreichischer Wirtschaftsprüfer (ed.), Wirtschaftsprüfer Jahrbuch 2000, pp. 251-283.

[8] Bundesfinanzministerium (2006), http://www.bundesfinanzministerium.de/cln_06/nn_54/sid_66

[9] Devereux, M. and H. Freeman (1991), A General Neutral Profits Tax, IFS

[10] Fehr, H. (1999), Welfare Effects of Dynamic Tax Reforms, Tübingen: Mohr-Siebeck.

[11] Fehr, H. / and Wiegard, W. (1999): Lohnt sich eine konsumorientierte Neugestaltung des Steuersystems?, in: Smekal, C. u.a.(Hrsg.): Einkommen versus Konsum, Heidelberg, S.65-84

[12] Fehr, H. and W.Wiegard (2003): ACE for Germany? Fighting for a Better Tax System. In: Ahlheim, M., Wenzel, H.-D., Wiegard, W. (Hrsg.): Steuerpolitik - Von der Theorie zur Praxis. Festschrift für Manfred Rose, Berlin u. a., 297-324.

[13] German Council of Economic Advisors (2005): Jahresgutachten 2005/06, Wiesbaden.

[14] German Council of Economic Advisors, Max Planck Institut, ZEW „Reform der Einkommens- und Unternehmensbesteurung durch die Duale Einkommensteuer " (Expertise im Auftrag der Bundesminister der Finanzen und für Wirtschaft und Arbeit)

[15] IFS Capital Taxes Group (1991), Equity for Companies: A Corporation Tax for the 1990S, The Institute for Fiscal Studies, Commentary No. 26

[16] Isaac, J. (1997), A Comment on the Viability of the Allowance for Corporate Equity, Fiscal Studies, 18, pp. 302-318

[17] Keen, M. and J. King (2002), The Croatian Profit Tax: An ACE in Practice, Fiscal Studies, vol. 23, No. 3, pp. 401-418.

[18] Keuschnigg, C. (1991), The Transition to a Cash Flow Income Tax, Swiss Journal of Economics and Statistics 127, pp. 113-140.

[19] Keuschnigg, C. and M. Dietz (2004), A Swiss Dual Income Tax For More Neutrality in Company Taxation, Swiss Journal of Economics and Statistics 140, pp. 483-519.

[20] Keuschnigg, C. and M. Dietz (2006), A Growth Oriented Dual Income Tax, forthcoming International Tax and Public Finance.

[21] Lammersen, L. (2002), Investment Decisons and Tax Revenues Under an Allowance for Corporate Equity, ZEW Discussion Paper No. 02-47.

[22] Miller, M.H. and F. Modigliani (1958), The Cost of Capital, Corporation Finance and the Theory of Investment, American Economic Review 48, pp. 261-297 
[23] President's Advisory Panel on Tax Reform (2006): Simple Fair and Pro Growth: Proposal's to Fix America's Tax System, Washington DC.

[24] Sinn, H.-W. (1987), Capital Income Taxation and Resource Allocation, Amsterdam: North-Holland.

[25] Sinn, H.-W. (1990), Taxation and the Cost of Capital: the "Old" View, the "New" View and Another View, NBER Working Paper No. 3501, Cambridge, MA.

[26] Sinn, H.-W. (1991), The Vanishing Harberger Triangle, Journal of Public Economics 45, pp. 271-300.

[27] Sørensen, P. B. (1995), Changing Views of the Corporate Income Tax, National Tax Journal 48, pp. 279-294.

[28] US Department of the Treasury (1992), Integration of the Individual and Corporate Tax Systems: Taxing Business Income Once, Washington DC: US Government Printing Office

[29] Wagner, F. (1999), Die Integration einer Abgeltungssteuer in das Steuersystem Ökonomische Analyse der Kapitaleinkommensbesteuerung in Deutschland und der EU, Steuerrecht, DB, Heft 30, pp. 1520-1528

[30] Zodrow, G. R. (1991), On the "Traditional" and "New" View of Dividend Taxation, National Tax Journal 44, pp. 497-509. 


\title{
CESifo Working Paper Series
}

\author{
(for full list see www.cesifo-group.de)
}

1788 George Kapetanios, M. Hashem Pesaran and Takashi Yamagata, Panels with Nonstationary Multifactor Error Structures, August 2006

1789 Torben M. Andersen, Increasing Longevity and Social Security Reforms, August 2006

1790 John Whalley, Recent Regional Agreements: Why so many, why so much Variance in Form, why Coming so fast, and where are they Headed?, August 2006

1791 Sebastian G. Kessing and Kai A. Konrad, Time Consistency and Bureaucratic Budget Competition, August 2006

1792 Bertil Holmlund, Qian Liu and Oskar Nordström Skans, Mind the Gap? Estimating the Effects of Postponing Higher Education, August 2006

1793 Peter Birch Sørensen, Can Capital Income Taxes Survive? And Should They?, August 2006

1794 Michael Kosfeld, Akira Okada and Arno Riedl, Institution Formation in Public Goods Games, September 2006

1795 Marcel Gérard, Reforming the Taxation of Multijurisdictional Enterprises in Europe, a Tentative Appraisal, September 2006

1796 Louis Eeckhoudt, Béatrice Rey and Harris Schlesinger, A Good Sign for Multivariate Risk Taking, September 2006

1797 Dominique M. Gross and Nicolas Schmitt, Why do Low- and High-Skill Workers Migrate? Flow Evidence from France, September 2006

1798 Dan Bernhardt, Stefan Krasa and Mattias Polborn, Political Polarization and the Electoral Effects of Media Bias, September 2006

1799 Pierre Pestieau and Motohiro Sato, Estate Taxation with Both Accidental and Planned Bequests, September 2006

1800 Øystein Foros and Hans Jarle Kind, Do Slotting Allowances Harm Retail Competition?, September 2006

1801 Tobias Lindhe and Jan Södersten, The Equity Trap, the Cost of Capital and the Firm’s Growth Path, September 2006

1802 Wolfgang Buchholz, Richard Cornes and Wolfgang Peters, Existence, Uniqueness and Some Comparative Statics for Ratio- and Lindahl Equilibria: New Wine in Old Bottles, September 2006 
1803 Jan Schnellenbach, Lars P. Feld and Christoph Schaltegger, The Impact of Referendums on the Centralisation of Public Goods Provision: A Political Economy Approach, September 2006

1804 David-Jan Jansen and Jakob de Haan, Does ECB Communication Help in Predicting its Interest Rate Decisions?, September 2006

1805 Jerome L. Stein, United States Current Account Deficits: A Stochastic Optimal Control Analysis, September 2006

1806 Friedrich Schneider, Shadow Economies and Corruption all over the World: What do we really Know?, September 2006

1807 Joerg Lingens and Klaus Waelde, Pareto-Improving Unemployment Policies, September 2006

1808 Axel Dreher, Jan-Egbert Sturm and James Raymond Vreeland, Does Membership on the UN Security Council Influence IMF Decisions? Evidence from Panel Data, September 2006

1809 Prabir De, Regional Trade in Northeast Asia: Why do Trade Costs Matter?, September 2006

1810 Antonis Adam and Thomas Moutos, A Politico-Economic Analysis of Minimum Wages and Wage Subsidies, September 2006

1811 Guglielmo Maria Caporale and Christoph Hanck, Cointegration Tests of PPP: Do they also Exhibit Erratic Behaviour?, September 2006

1812 Robert S. Chirinko and Hisham Foad, Noise vs. News in Equity Returns, September 2006

1813 Oliver Huelsewig, Eric Mayer and Timo Wollmershaeuser, Bank Behavior and the Cost Channel of Monetary Transmission, September 2006

1814 Michael S. Michael, Are Migration Policies that Induce Skilled (Unskilled) Migration Beneficial (Harmful) for the Host Country?, September 2006

1815 Eytan Sheshinski, Optimum Commodity Taxation in Pooling Equilibria, October 2006

1816 Gottfried Haber and Reinhard Neck, Sustainability of Austrian Public Debt: A Political Economy Perspective, October 2006

1817 Thiess Buettner, Michael Overesch, Ulrich Schreiber and Georg Wamser, The Impact of Thin-Capitalization Rules on Multinationals' Financing and Investment Decisions, October 2006

1818 Eric O’N. Fisher and Sharon L. May, Relativity in Trade Theory: Towards a Solution to the Mystery of Missing Trade, October 2006 
1819 Junichi Minagawa and Thorsten Upmann, Labor Supply and the Demand for Child Care: An Intertemporal Approach, October 2006

1820 Jan K. Brueckner and Raquel Girvin, Airport Noise Regulation, Airline Service Quality, and Social Welfare, October 2006

1821 Sijbren Cnossen, Alcohol Taxation and Regulation in the European Union, October 2006

1822 Frederick van der Ploeg, Sustainable Social Spending in a Greying Economy with Stagnant Public Services: Baumol’s Cost Disease Revisited, October 2006

1823 Steven Brakman, Harry Garretsen and Charles van Marrewijk, Cross-Border Mergers \& Acquisitions: The Facts as a Guide for International Economics, October 2006

1824 J. Atsu Amegashie, A Psychological Game with Interdependent Preference Types, October 2006

1825 Kurt R. Brekke, Ingrid Koenigbauer and Odd Rune Straume, Reference Pricing of Pharmaceuticals, October 2006

1826 Sean Holly, M. Hashem Pesaran and Takashi Yamagata, A Spatio-Temporal Model of House Prices in the US, October 2006

1827 Margarita Katsimi and Thomas Moutos, Inequality and the US Import Demand Function, October 2006

1828 Eytan Sheshinski, Longevity and Aggregate Savings, October 2006

1829 Momi Dahan and Udi Nisan, Low Take-up Rates: The Role of Information, October 2006

1830 Dieter Urban, Multilateral Investment Agreement in a Political Equilibrium, October 2006

1831 Jan Bouckaert and Hans Degryse, Opt In Versus Opt Out: A Free-Entry Analysis of Privacy Policies, October 2006

1832 Wolfram F. Richter, Taxing Human Capital Efficiently: The Double Dividend of Taxing Non-qualified Labour more Heavily than Qualified Labour, October 2006

1833 Alberto Chong and Mark Gradstein, Who's Afraid of Foreign Aid? The Donors' Perspective, October 2006

1834 Dirk Schindler, Optimal Income Taxation with a Risky Asset - The Triple Income Tax, October 2006

1835 Andy Snell and Jonathan P. Thomas, Labour Contracts, Equal Treatment and WageUnemployment Dynamics, October 2006 
1836 Peter Backé and Cezary Wójcik, Catching-up and Credit Booms in Central and Eastern European EU Member States and Acceding Countries: An Interpretation within the New Neoclassical Synthesis Framework, October 2006

1837 Lars P. Feld, Justina A.V. Fischer and Gebhard Kirchgaessner, The Effect of Direct Democracy on Income Redistribution: Evidence for Switzerland, October 2006

1838 Michael Rauscher, Voluntary Emission Reductions, Social Rewards, and Environmental Policy, November 2006

1839 Vincent Vicard, Trade, Conflicts, and Political Integration: the Regional Interplays, November 2006

1840 Erkki Koskela and Mikko Puhakka, Stability and Dynamics in an Overlapping Generations Economy under Flexible Wage Negotiation and Capital Accumulation, November 2006

1841 Thiess Buettner, Michael Overesch, Ulrich Schreiber and Georg Wamser, Taxation and Capital Structure Choice - Evidence from a Panel of German Multinationals, November 2006

1842 Guglielmo Maria Caporale and Alexandros Kontonikas, The Euro and Inflation Uncertainty in the European Monetary Union, November 2006

1843 Jan K. Brueckner and Ann G. Largey, Social Interaction and Urban Sprawl, November 2006

1844 Eytan Sheshinski, Differentiated Annuities in a Pooling Equilibrium, November 2006

1845 Marc Suhrcke and Dieter Urban, Are Cardiovascular Diseases Bad for Economic Growth?, November 2006

1846 Sam Bucovetsky and Andreas Haufler, Preferential Tax Regimes with Asymmetric Countries, November 2006

1847 Luca Anderlini, Leonardo Felli and Andrew Postlewaite, Should Courts always Enforce what Contracting Parties Write?, November 2006

1848 Katharina Sailer, Searching the eBay Marketplace, November 2006

1849 Paul De Grauwe and Pablo Rovira Kaltwasser, A Behavioral Finance Model of the Exchange Rate with Many Forecasting Rules, November 2006

1850 Doina Maria Radulescu and Michael Stimmelmayr, ACE vs. CBIT: Which is Better for Investment and Welfare?, November 2006 